\title{
THE INTRODUCTION OF ENGLISH LAW INTO ALBERTA
}

J. E. COTE*

I

The majority of the Canadian provinces follow the common law tradition, and do not have a Code to lay down the principles of their law, nor do Imperial, federal, or provincial statutes cover more than a fraction of the entire area of the law. In England this gap has been filled up over centuries by a process of gradual accretion, through the decisions of thousands of judges. No Canadian province is old enough for this process to have produced a reasonably complete body of judge-made law, however, so that in every case resort is had to English law to fill in the gaps not dealt with by statutes.

Such a solution has come naturally, for all the common law provinces were at one time English colonies or parts of colonies, and so subject to the rules of the common law governing the migration of English law to new colonies. The basic outlines of this process have been settled for over three hundred years, and may be briefly sketched here. A colony conquered from a European ruler and possessing its own civilized laws is deemed to retain its law until the English monarch sees fit to alter it,' but this rule has no application to any of the Canadian common law provinces, all of which (even Nova Scotia) have been held to have been not conquered, but acquired by settlement. ${ }^{2}$ In a settled colony, the first colonists on arrival are deemed to bring with them such of the laws of England as are reasonably applicable to the circumstances of the new colony. ${ }^{3}$ This doctrine is probably a survival of the Medieval notion of personal allegiance, which could be lost only by becoming the subject of another sovereign. Therefore in a settled colony the law would be the law of England as it existed on the founding of the settlement, except where inapplicable to the colony, or where changed since by local statutes, or by Imperial statutes extending to that colony." This is the situation in all the Maritime provinces, the relevant dates

- B.A. (Hon.) (MeGIIJ), LL.B. (Alta.) of the Gradunting Clngs of 1964, Unjversity of Alberta.

1 Calvin's Case (1609) 7 Co. Rep. 1a: 77 E.R. 377; 2 How. St. Tr. 599; sec especlally p. $17 a$ (Ca. Rep.); Campbell v. Hall (K.B. 1774) 20 How. St. Tr. 230, 320, 329; see also note (1722) 2 Peere Wms. 75, 24 E.R. 646.

2 Dawson, Government of Carada 5-6 (3d ed. 1957): Clements' Caradian Constitution 280-81 (3d ed. 1916). Thls is not true of those parts of Osstarlo ceded by France to Britain in 1763, but as noted below, the same result has been achteved throughout Ontarjo by statute.

3 Calvin's Case, sujra; 1 B1. Com, 107; A.-G. v. Stewart (Ch. 1817) 2 Mer. 143, j5 E.R. 895; Cooper v. Stuart (P.C. (N.S.W.) 1889) 14 App.Cas. 286, 291-92; Gray, Nature and Sources of the Law 196-97 (2d ed. 1921).

1. Thls is the posttion taken by Windeyer, $A$ Birthrioht and Interitance (1002) 1 Tas. U. L. Rev. 635. But on naturallzation, and loss of personal aljeglance. ef. the Report of the Commissloners on Naturalization (1870) and the common law before 1870: $R$. $v$ Story (Q.B. 1571) 1 How. St. Tr. 1087, 1090, 1091; R. v. Macdonald (K.B. 1747) 18 How. St. Tr. 858, 859 .

3 We must therefore carefully distingulsh British statuteg in force thla way from those In force proprio vioore. Statutes In force yroprio vigore are (glnce the Colonlat Laws Valldity Act, 1865 (Imp.) 28 \& 29 Vict. c. 63) those expressly or Implled intended to be in lorce in the colony, whereas those whlch are dealt with in this essay were intended to apply when enacted only to England, and have been transplanted as part of the taw of England to the new colonies. The process somewhat resembles a Elant Incorporation by reference. See A.-G. Alta. v. Huggard Assets Ltd. (P.C. (Can.) 1953) 8 W.W.R. (N.S.) 561, 569-70, and Bank of Upper Canada v. Bethune (C.A. 1833) 4 U.C.Q.B. (O.S.) 165. $171 \mathrm{ff}$. 
for the reception of English law being 3 October 1758 for Nova Scotia and New Brunswick, 7 October 1763 for Prince Edward Island, and 31 December 1832 for Newfoundland. ${ }^{\circ}$

In Ontario (Upper Canada) and British Columbia the situation is much the same, except that legislation has since been passed codifying the common law rule. Ontario received English law as of 15 October 1792, and British Columbia as of 19 November 1858.

The situation in Western Canada is a little more complicated, however. The first settlements in many areas were most probably French fur trading posts, but they had little permanence, and few people seem seriously to have advocated the view that the Prairies, like Quebec, were a conquered colony rather than a settled colony. ${ }^{B}$ This view is largely due to the fact that most of this area was included in the grant made to the Hudson's Bay Company on 2 May 1670. Not only did the Company introduce settlers and so by force of common law introduce English law, but the charter of the company, in granting governmental powers over Rupert's Land to the Company, established the law of England over that territory." The importance of introduction of English law by settlers lies in the fact that a little of the Prairies and most of the North were not included in Rupert's Land, and so were not subject to the Company's Charter. ${ }^{10}$ Though the Company had governmental powers, it did little to exercise them until the founding of the Selkirk colony." For the areas outside this colony, the only provision made for the administration of justice was contained in Imperial statutes allowing the

- Falconbridgc, Banking and Bitls of Exchange 11, 12 (6th ed. 1956). 3 October 1758 is the date of meeting of the flrst general assembly of Nova Scolla (which then Included what is now New Brunswlek), and the date given for Prince Bdward Island was set by proclamation. The first Newfoundland assembly met on 1 January 1833 . See Young v. Blatkie (1822) i Nnd. R. 277, 283, Ct. Windeyer, loc. cit. supra, 667.

- (U.C.) 32 Geo. 3 c. 1 8. 3, now the Property and Civll Rlghts Act, R.S.0. 1860 c. 310 , and (U.C.) 40 Geo. 3 c. 1 for criminal law (now covered by the Crininal Code as noted below, nn. 99, 102.) As the Canadian constitution is now interpreted, "property and clvil rlghts" is somewhat narrower than clvil (non-crimlnal) law. If then the terms of the 1792 statute of Upper Canada are narrower than those of the Quebec Act, 1774 of the 1792 statute of Upper Canada are narrower than those of the Quebec Act, 1774 ,
is the law of Canada (l.e. New Erance) stlll in force in the parts of Ontarlo included in the old province of Quebec (as deflned under the 1774 statute) for some subjects? For Britush Columbia, see the Governor's Proclamation of 19 November 1858, extended to the mainland by 34 Vict. (1871) no. 70. now found in the English Law Act, R.S.B.C. 1960 c. 129 .

See also R.S.C. 1952 c. 85 on the law of divore In Ontario.

When these provinces entered Confederation. 5. 129 of the British North America Act. 1867 of course applied to them, continuing in force the existing law.

8 Sinclair v. Mulligan (Man. C.A. 1888) 5 Man. R. 18; A.-G. Alta v. Huggard Assets Ltd. supra, and Walker v. Walker (P.C. (Man.)) [1919] 2 W.W.R. 935, 936-37 take the vlew that only Engllsh law prevalled, though some question has been ralsed by McCaul Constitutional Status of the North-West Territorles (1884) 4 Can. L.T. 1, 9-13, and Anglin J. In Trusts \& Guarantoc Co. v. R. (1916) 54 S.C.R. 107, 125. In any event, subsequent legislation has rendered the question hypothetical.

- 1 Ollver, The Caredian North-West 75-76, 144-45, 149 (1914).

30 id. at 143.

11 td. at 30-39, 75 ff., 86-90, 154. The Hudson's Bay Company's leglslative council for Assinibola on 11 April 1862 introduced the law of England as of the date of Queen Victorla's accession (20 June 1837), and then on 7 January 1864 introduced Engllsh law as of that date (R.S.M. 1881 p. lxxix), but as seen below, thls was later changed by legislation, though it caused confusion for a time, the effect of these ordinances being said to be though it caused confusion for a time, the effect of these ordinances being said to be supra, at 13, Walleer v. Walker, supra, at 936-37; Oilver, op. ctt. supre 1323, 1330, 1346-47. 
hearing of causes from the Northwest in the courts of adjoining colonies, ${ }^{12}$ but the authorities for the most part ignore the possibility that the law of Upper Canada was thereby introduced into these territories. ${ }^{19}$

After the establishment of the Province of Manitoba, some confusion arose as to the date on which English law was received in that area, ${ }^{14}$ and a number of statutes were passed to clarify the situation. Both Manitoba and the Dominion passed declaratory acts naming $15 \mathrm{July}$ 1870 (the date of admission of Manitoba into Confederation) as the date on which English law was received into that province ${ }^{15}$ and these have continued in force since, covering between them the whole field of legislative competence. In the rest of the Territories, the Legislative Assembly of the Territories passed an ordinance of doubtful validity adopting the same date as that used by Manitoba for the reception of English law into the Territories. ${ }^{10}$ This ordinance was, however, soon superseded by the North-West Territories Act of the Dominion, appointing the same date, 15 July 1870, for the reception of English law, and expressly excepting such English law as was "inapplicable".17 This Act was subjected to several minor amendments (notably in the revision of 1886) ${ }^{18}$ but still continues in force today and governs the present

12 (Imp.) 43 Geo. 3 c. 138 provided for the trial of criminal offences in the territory not included in the Canadas or the U.S.A., in the courts of Upper or Lower Canada, with punishment according to the laws of the plnce of trial. After Lord Selkirk obtained an opinion that this Act did not apply to Hudson's Bay Company territories, (Imp.) 1 \& 2 Geo. 4 c. 66 8. 5 was passed, deeming the statute of 43 Geo. 3 to extend to this area, all other laws and statutes non obstante. By 8.6 all contracts, agreements, debts, liabilities. ond demnis or wrones or injurles to the person or property, real or personal, were to be tried in Upper Canada as though arising there, the consequences of the lawgult to be tried In Upper Canada as though arising there, the consequences of the lawsult to land were involved, in whlch case English law was to apply without the admlxture of any local Upper Canada statutes. (Imp.) 22 \& 23 Vict. c. 26 affirmed the previous legislation and the powers under it (never excrcised) to appoint courts of summary Jurlsdiction for the territory. Summary trials for offences arising in this area by the new statute might be held in Brltish Columbla or Upper Canada. This Act was not to extend to Hudson's Bay Company territory. Britlsh Columbla, or Vancouver Island. to extend to Hudson's Bay Company territory, Britsh Columbla, or Vancouver Island. One may note that (Can.) 38 Vlct. 4.4953 . 64, 65,71 and 73 somewha

13 See the authorities cited in note 8, supra, but cf. MeCaul, loc. cit. supra 14, 15. MeCauls view is on principle easier 10 understand, for the provisions of $1 \& 2$ Geo. 4 c. $66 \mathrm{~s}$. 6 referred to above seem clearly to provide for the settlement of suits by the law of Upper Canada. In any event, the later leglslation clarified the sltuntion.

For a seneral history of the subject, see Ollver, op. cit. supra 20-39, 75-90; Harvey. The Early Administration of Justice in the North-West (1934) 1 Alta. L.Q. 1; Brown British Stattites in the Emerging Nations of North America $(1963) 7 \mathrm{Am}$. J. Lert. Hlst. 95.

14 See the memorandum by J.B. Cosne, K.C. In The British North America Act and Amendmonts, 1867-1948, p. 184 (KIns's Printer, Ottawa, 1948). (This appears at p. 204 in the 1962 cditlon.) Sinclair $v$. Mulligan, supra.

15 (Man.) 38 Viet. c. 12, now R.S.M. 1954 c. 52, 8. 50; (Can.) 51 Vlet, c. 33 s. 1 , now R.S.C. 1927 c. $124 \mathrm{~s} .4$ (not repealed in 1952, and atill In force). deeming the law of Fngland to have been in force as of 15 July 1870 since that dote insofar as relates to matters within the lefislntive competence of the Parliament of Canada. It is to be noted that the present Manltoba statute contains a proviso saving rights acquired under the laws of Assinibola, so the Issue raised In Sinciair $v$. Mulligan may not be dead even yet.

16 Ordinance No. 26 of 1884 s. 1 (Aug. 6); see (1800) 1 Terr. L.R. Xvil. This ordinance was probably Invalld because it conflicted with (Can.) 32-33 Vict. c. 3 s. 5, which presumably continued in force English law as of 2 May 1670 . For a general history of this period see Oliver, op. cit. supra 115-19.

17 (Can.) 49 vict. c. 25 s. 3 :

"Sublect to the provislons of the next preceding section the laws of Braland relating to civil and crimlnal matters, as the same existed on the 15th day of July, in the year of our Lord one thousand elght hundred and seventy, shall be in force in the Terrltorles, In 50 far as the same are applleable to the Terrltortes, and in 80 lar as the same have not been, or may not hereafter be, repealed, altered, varled. modifled, or affected by any Act of the Parliament of the United Kingdom applicable to the Territorles, or of the Parliament of Canada, or by any ordinance a the Iteutenant-Gavemor in Councll."

18 In the same year R.S.C. 1886 c. 50 8. 11 replaced the above provision with a slightly different wording:

"Subject to the provislons of this Act, the laws of Bngland relating to civil and criminal matters, as the same exlsted on the fifteenth day of July, in the year of our ford one thousand eight hundred and seventy, shall be in lorce in the Territorles. in so far as the same are appllcable to the territories, and in 30 far as the same have not been, or are not hereafter repealed, altered, varied, modifled, or affected by any Act of the Parllament of the Unlted KInsdom applicable to the Territories. or of the Parliament of Canada, or by any ordinance of the Lleutenant Governor or of the Parit

(Can.) 60-61 Vict. c. 28 s. 4 added to the end of this section the words "or of the Lefinlative Assembly." 
Northwest Territories ${ }^{10}$ and Yukon. ${ }^{20}$ It was therefore in force when in 1905 the new provinces of Alberta and Saskatchewan were established, the relevant Acts ${ }^{21}$ providing that the law existing in the Territories was to continue in the new provinces until modified by legislation. Therefore, for Alberta and Saskatchewan the relevant statutory provision, dating from 1886 and amended since, is as follows:

"Subject to the provisions of this Act the laws of England relating to civil and criminal matters, as the same existed on the fifteenth day of July, in the year of our Lord one thousand eight hundred and seventy, shall be in force in the Territories, in so far as the same are applicable to the Territories, and in so far as the same have not been, or are not hereafter, repealed, altered, varied, modified, or affected by any Act of the Parliament of the United Kingdom applicable to the Territories, or of the Parliament of Canada, or by any ordinance of the Lieutenant-Governor in Council, or of the Legislative Assembly."

It is to be noted that this section (unlike the one for Manitoba ${ }^{22}$ ) is not expressed to be retroactive, and so presumably transactions before 18 February 1887 are governed by the law of England of 1670, or whatever other date may have been relevant before the passage of this statute. ${ }^{32 a}$

It is the purpose of this article to examine the use which the courts have made of these provisions, and what implications they have for the general administration of law in the Canadian West, with particular reference to the decisions of Alberta courts.

\section{II}

Before we consider in more detail the meaning of the term "applicable" in the statute quoted above, a few general remarks may be made. Though this enactment and the common law rule it replaced have been taken to apply to statutes as well as to the unwritten law, and to rules of equity as much as legal rules, ${ }^{23}$ nevertheless ecclesiastical law

10 R.S.C. 1952 c. 331 s. 17.

20 (Can.) 61 Vict. c. 6 s. 9, now R.S.C. 1952 c. 298 s. 33.

21 The Alberta Act (Can.) 4-5 Ed. 7 c. 3 8. 16; The Saskatchewan Act (Can.) 4-5 Ed. 7 c. 42 s. 16.

23 See R.S.C. 1927 c. 124 s. 4.

:*a Maxwell on Interpretation of Statutes 204-220 (11th ed. 1962), Crates on Statute Law 388-404 (6th ed. 1963).

23 Falconbridge, op. cit. sumg 426 surgests that the Act of 1886 was not Intended to introduce rules of equity, as only the word "law" was used, nnd that the substantive rules of equlty have been introduced into the Canadlan common law provinces only by provinclal Judicature Acts modelled upon the English Acts of 1873 and 1875 . He supports this conclusion with reference to the history of Upper Canada, as descrlbed by him in (1914) 63 U. Pa. L. Rev. 1. reprinted in 34 Can. L.T. 1130. It is submitted. however. with the areatest respect, that this conclusion is unacceptable for several reasons. In the first place, the decisions of the courts of Upper Canada that the rules of equity were not in force there seemed to be based as much on the fact that they had not been Eiven equitable jurisdiction, as upon the wording of the 1792 that they had not been Eiven equitable jurisdiction, as upon the wording of the 1792
statute. In the second place, the word "laws" can at least as easlly be interpreted as referring to all the rules of decision used by the English courts, and such a construction is to be preferred. for it will avold the inconvenience and absurdity which would result if English legal rules and English statutes were enforced without any equilable rules. Such $n$ use of the phrase "laws of England" is found in the Judicature Act, R.S.A. 1955 c. 164 s. 16. Thirdly, the Judicature Act's key sectlons are modelled on the English Act, whlch ns Maltland polnted out. is desitned to grant and to allocate powers and jurisdiction of courts, not to change the substantive rules which they are to powers and Jurisdictlon of courts, not to change the substantive rules which they are to of the Judicature Act appear on thelr face to be merely provisions as to remedles and reljel, not as to substantive rules, nor do they give any date as of which English rules are to be applled, while s. 34(13), based on the famous English enactment. simply assumes that there are in force cquitable rules (which might clagh with legal ones). (But as noted in the text of this essay, the meaning of $\mathrm{s}$. 32 is not beyond doubt.) Finally, western Canadian courts have been applying rules of equity for generations without reference to the Judicature Act to see whether the rule in question is provided for in that Act, and they have applied the Act of 1886 when dealing with statutes upon equitable toples. We may note that the Court of Chancery in Nova Scotia from the beginning followed substantlve Engligh rules of equity. Townsend. History of the Court of Chancery in Nova Scotia (1901) 20 Can. L.T. 14, 37, 74, 105. Accord, 15 Corpus Jurts Secundum 614 (8. 13), 616 (s. 8). 
and local custom of individual parts of England seem never to have been transplanted to the New World."

However, though there should be no difference between the applicability of statutes and common law rules, in most provinces, especially in the Maritimes, ${ }^{23}$ the courts have been much more ready to apply English common law rules than to apply English statutes. In principle this seems strange, all the more because the statutes are in a great many cases designed to remedy defects in the common law. The answer, however, probably lies to a great extent in methods of legal research. English reports of decisions, digests, and textbooks have from a very early time been available in all new colonies, so much so that English cases are often looked on not as being merely persuasive, or as expressing a rule which may or may not be applicable for some special reason, but simply as expressing "the law" which is to be followed in precisely the same way as would a domestic decision. English statutes, on the other hand, have until recent times been extremely bulky, prolix, disorderly, and expensive. Few libraries have possessed a set of the Statutes at Large, and if they have it has done little good for want of any serviceable arrangement or index of the statutes, or a pruning out of repealed, obsolete, or inapplicable legislation. This rearrangement and pruning has been done in England in recent years, ${ }^{20}$ but is of little help to one who wishes to determine what the law of England was in 1870, 1858,1792 , or $1758 .{ }^{2 i}$ The practical result, therefore, has been that whatever may be the onus of proof in establishing whether a rule of common law or a statute is in force, the "onus of research" has been on him who wished to prove that an English statute was in force, with a few obvious exceptions, such as Habeas Corpus, ${ }^{28}$ the Statute of Limitations, ${ }^{29}$ the Statute of Frauds ${ }^{30}$ and 13 Eliz. c. 5 on fraudulent conveyances. ${ }^{31}$

What does the North-West Territories Act mean when it refers to such of the laws of England as are "applicable"? The courts have taken the word "applicable" in the statute to refer not to the mere physical possibility of applying the English common law or legislation, ${ }^{32}$ but its

24 Re Ld. Bishop of Natal (P.C. (Cape Col.) 1864) 3 Moo. P.C. N.S. 115, 152-53: 16 E.R. 43. 57; Gray v. Nat. Trust Co. (S.C. Alta 1915) 8 W.W.R. 1061: In re Seidler (S.C. Alta.) [1929] 2 W.W.R. 645; Vamrakldis v. Kirkoff (Ont. C.A.) [1930] 2 D.L.R. 877; cl. is Corpus Juris Secundum 616 (s. 7), and Dale, The Adoption of The Common Lav by the American Colonies (1882) 30 U. Pa. L.Rev. (O.S.) 353, 562 if. But cf. Baine, Johnstone \& Co. v. Chambers (1819) 1 N/d. R. 154, 156; Blshop of Columbia v. Cridge (S.C. B.C. 1874) 1 B.C.R. (pt. 1) 5 .

2s Clements' Canadian Constitution 280-81 (3d ed. 1916).

20 Allen. Law in the Making 426-28 (6th ed. 1958).

27 The solution 80 far as English statutes in force on 15 July 1870 are concerned seems to be to consult the 1st edition of the Queen's Printer's Chronological Table and Index to the Statutos in Force (London, 1870). Which glves a subject Index of all statutes in force at the end of $32 \& 33$ vict. (the 1869 session), thus omitting only 30 more Acts which recelved royal assent between then and $15 \mathrm{July} 1870$ (that ls, the first 30 chapters of 33 \& 34 Vlat.)

28 (Imp.) 1 \& Ph. \& M. c. 13; 31 Car. 2 c. 2.

20 (Imp.) 21 Jac. I c. 16 modifled by (Imp.) 4 Anne c. 16; see U.S. Savings \& Loan Co. v. Rutledge (Y.T. en banc 1903) 2 W.L.R. 471: Plano etc. Co. v. Peterson (S.C. 1906) 3 W.L.R. 565,567 , holding these two statutes to be in force.

so (Imp.) 29 Car. 2 c. 23.

31 C. Connors v. Egli (Alta. C.A.) [1924] 1 W.W.R. 1050.

s2 Cl. Plested v. MCLeod (Suzk. D.C. 1910) 12 W.L.R. 700, R. v. O'Connor (Man. Q.B. en banc for N.W.T. 1885) 1 Terr. L.R. 4, 11-12, 13. 
reasonable suitability to the new territories, ${ }^{83}$ thus in effect treating the Act of 1886 as being a codification of the common law rule, ${ }^{34}$ with the exception of the fixing of a new date. It is further submitted that in the light of the leading authorities, ${ }^{35}$ by far the most informative statement of the meaning of applicability is still that given by Blackstone: ${ }^{30}$

"For it hath been held, that if an uninhabited country be discovered and planted by English subjects, all the English laws then in being, which are the birthright of every subject, are immediately there in force. But this must be understood with very many and very great restrictions. Such colonists carry with them only so much of the English law as is applicable to their own situation and the condition of an infant colony; such, for instance, as the general rules of inheritance, and of protection from personal injuries. The artificial refinements and distinctions incident to the property of a great and commercial people, the laws of police and revenue, (such especially as are enforced by penalties,) the mode of maintenance for the established clergy, the jurisdiction of spiritual courts, and a multitude of other provisions, are neither necessary nor convenient for them, and therefore are not in force."

When considering whether a statute or rule of English law is applicable to some part of the Commonwealth such as Alberta, the time at which the test is to be applied will be very important, for most of the reasons why such a rule might be inapplicable have to do with social and economic conditions rather than physical conditions such as climate or soil. Physical conditions remain the same over centuries, but social conditions vary greatly, the Northwest Territories in 1886 being a very different place from Alberta in 1964 or 2064. England in 1291 or 1886 was a very different place from "Alberta" then or now, but it is less easy to predict that social conditions existing in England in the past will never be relevant in Alberta in the future.

There are five different times which might be relevant in deciding whether any statute or rule of law is applicable:

(1) the time that the rule was first enunciated or the statute received royal assent, in England

(2) 15 July 1870 (the date on which English law is chosen for reception into Manitoba, Saskatchewan, and Alberta)

(3) 18 February 1887 (the date on which the North-West Territories Act came into force)

(4) the date on which this particular rule of law was first considered by a court in Alberta (or another part of the Canadian West?)

(5) the present date.

Because on any question as to the applicability of a given rule of law the social conditions of England and of Alberta have to be compared, conditions in each of these areas might be considered at any one of the five times, thus yielding $5^{2}$ or 25 different formulas, ranging all the way from consideration of both English and Canadian sociàl conditions at the time the rule of law was first formulated in England, through 33 Gray, op, cit. supra 196-97; Windeyer, loc. cit. supra at 668: Fraser V. Klrkpatrick (S.C. re Simpson Est. (A]ta. C.A.) [1927] 3 W.W.R. 534, 537-38; Clarke v. Bdmonton [1930]
S.C.R. 137.

Contra, Stuart J. dissentlng in Mackowocki y. Yachimyc (Alta. C.A. 1917) 11 W.W.R. 1279, 1284: Delohery v. Perm. Trustee Co. (1904) 1 C.L.R. 283, 310 (but cf. Quan Yick v Hinds (1905) 2 C.L.R. 3A5, and its double test of unsultablity or inapplicability). If a rule is incapable of appllcation it must also be unsultable: the Quan $Y$ ick case, at 356.
But cf. $n .47$ infra.

34 Cf. 1 Bl. Com. 107, quoted infra.

35 See n. 33 supra.

301 Bl. Com. 107 
consideration of that time in England and social conditions in the Northwest Territories on 15 July 1870, to consideration of both English and Canadian social conditions at the present date.

We can, however, eliminate several possibilities immediately, for it is obvious that the social conditions of the Northwest Territories or Rupert's Land at any time much before 1870 are likely to be of no use. Before the early 19 th century there were no permanent white settlers in the area, and so very few laws other than the simplest criminal law were necessary. Indeed, before 1760, a large proportion of the Europeans present were not English, and before 1670 probably none were. The mere fact that the problems for consideration is the introduction of English law into a "new colony" shows that the circumstances of the "colony" are relevant at some date later than that of the first enunciation of the rule of law in question, which may far antedate even Columbus' voyages to the New World. Therefore number (1) can apply only to social conditions in England, and we are reduced to (5 x 4) 20 possible formulas.

There are two more dates which can be eliminated, though possibly they are not quite so obvious. If the law of England which is to be introduced is that of $15 \mathrm{July} 1870$, then any change in law or social conditions in England since then can have no direct relevance. ${ }^{38}$ It is not the law of England of 1886 or any later date with which we are concerned, and therefore as we do not have to consider whether the law of England in $\mathbf{1 8 8 6}$ or any later date is applicable we need not consider English conditions after 1870 . Therefore numbers (3), (4), and (5) can apply only to conditions in Alberta, and we are left with $(2 \times 4) 8$ possible formulas, which involve considering English conditions at the time of the introduction of the rule or in 1870, and consideration of Canadian conditions in 1870,1887 , on first consideration by local courts, or at the present.

It is also probable that 1887 (when the North-West Territories Act of $1886^{30}$ came into force) or 1886 (when it received royal assent ${ }^{10}$ ) can be eliminated, for the mere accident of date of passage of an Act should not govern the time from which the Act speaks. This is all the more notable in that the tense in which the relevant provision was written was changed between the North-West Territories Act of 1886, and the version which appeared in the Revised Statutes of Canada of the same year. ${ }^{\star 1}$ And in any event, it is a cardinal rule of interpretation that a statute is to be read as always speaking, and the Alberta and Canada Interpretation Acts so provide."2 As the provisions of these two Acts are the same, it is unimportant which governs the North-West Territories Act of 1886 in its capacity as part of the law of Alberta within the competence of the Alberta legislature. It would, however, probably be taking this rule

37 Jex v. McKinney (P.C. (Br. Hond.) 1889) 14 App.Cas. 77, applled in Re Simpoon Est., supra.

sa Of course evidence that the emanclpation of women In England led to the abolltion of some rule in 1925 in England would be good evidence that the old rule is not appllcable to Alberta, where women are simllarly emanclpated, but that is another matter.

30 (Can.) 49 Vict. c. $25 \mathrm{s.}$ 3, whlch came into force on $18 \mathrm{Feb}$. 1887, by Order In Council of 21 January 1887. See (1900) 1 Terr. L.R. xix.

102 June 1886.

1 See n. 27, supra.

42 Interpretation Act, 1958 (Alta.) c. 32 8. 6(1); Interpretation Act, A.s.C. 1952 c. 158, 8. 10. 
of construction too far to use it as our sole basis for deciding that the only date appropriate for the consideration of social conditions in Alberta could be the present date (though that is an entirely possible conclusion on broader grounds, as will be shown below.) Thus the possibilities are reduced to $(2 \times 3) 6$.

A little reflection will show that the date on which the rule first came to be considered by Alberta courts cannot be the relevant date either, even though the decision by them may be binding. Consider, for instance, Board v. Board ${ }^{4 s}$ in which the Judicial Committee of the Privy Council held in 1919 that the Divorce and Matrimonial Causes Act of 1857 had been introduced into the Territories. This is undoubtedly a binding decision on any Alberta court, but without for the moment looking at the actual words of the decision, let us consider what it must mean. The Privy Council cannot have held that the Act was applicable because of social conditions in Alberta in 1964, for they did not know what social conditions in Alberta in 1964 would be. Therefore they must have based their judgment on conditions in Alberta in 1919 (or the beginning of the suit), or at some earlier time, such as 1870. And if it was 1919 (or the beginning of the suit) then they were choosing what was for them "the present date", which is our number (5) above. Therefore, our number (4) cannot be the proper date for the examination of Alberta law, and indeed it would be ridiculous that it should be relevant, for the mere accident of the time of bringing an action should not decide for once and for all whether a certain rule is or is not applicable. After all, what if the Privy Council had decided in Board v. Board ${ }^{18}$ that the Act of 1857 was in force only because of unusual social conditions present in Alberta in the wake of World War I?

The remaining question as to whether the relevant date at which conditions in Alberta should be examined is 1870 or the present date is 'very difficult, as Story"4 points out. Was the introduction of English law an instantaneous process, a sudden transplantation of all the law which in 1870 was applicable to the crude condition of the Territories, or is it a continuous process whereby rules of law which were formerly not applicable to the simple circumstances of the Canadian West may become applicable as social conditions change and the economy develops? Is a decision in 1919 that the Divorce and Matrimonial Causes Act, 1857 is in force a decision binding for all times, or is it only a decision that the Act was in force in 1919, and is thereafter only rebus sic stantibus?... The authorities differ markedly upon this subject ${ }^{45}$ and as it is submitted that none of them are decisions on the point by way of ratio binding on Western Canadian courts, we must consider the question upon principle. Of course the question is not likely to arise often, for the applicability of English statutes and common law rules is not often raised, nor is it likely that in many cases such an evident change in social conditions will have occurred that counsel will seek to avoid an earlier decision upon the

13 (P.C. (Alta.)) [1919] A.C. 958, affo. (Alta. C.A.) [1918] 2 W.W.R. 633.

1 I Story on the Constitution 104-05 (5th ed. 1891).

40 The clearest authority for appllcabllity from time to time Is Cooper v. Stuart (P.C. (N.S.W.) 1889) 14 App.Cas. 269, 291-92; though Ontario and New Brunswick courts seem to agree with this approach more than do Nova Scotis courts (Falconbridge, op. clt. supra at 11. Clements op, cit. supra at 277, 280). Contra, Quan Yick v. Finds, supra, at 367, 378: Mitchell v. Scales (1907) 5 C.L.R. 405. In re Simpson Est, supra, does not really deal with this point, but a valuable discussion is found in Castles, Reception and Status of English Law in Australla (1963) 2 Adel. L. Rev. 1, 8-9, 16. 
subject. This is all the more true because Canadian society is growing wealthier and more complex, so that more and more rules of property and trusts found in English law will come to bear some relevance to Canadian conditions. The rule in Allhusen v. Whittell's is an example. It is in the nature of such a rule, however, that it is unlikely to be raised by counsel until conditions have reached the point at which the rule will bear some relevance to the problems at hand, and so it is unlikely that decisions will be found in which such a rule has been held inapplicable. Therefore questions of whether to follow such decisions will rarely arise. When they do come up, however, the better course would be to consider the applicability of the rule or statute at the present time, ${ }^{17}$ for three reasons. In the first place, as noted above, the law should be read as always speaking, and so the 1886 statute is to be read as referring to applicability from time to time. The 1886 statute says "insofar as the same are applicable" [italics added], not "were applicable". In the second place, the selection of 1870 as the date for consideration of applicability to the Territories would be arbitrary and senseless: why not 1869 just as well, or 1670 for that matter? A precise date is necessary only to define the body of law which may be applicable; no fixed and immutable date for determining applicability is necessary. Finally, we should seek to interpret the statute in such a way as to produce the most convenient result possible, and this will be achieved by selecting those rules of law which are fitted to our needs, not our grandparents' needs.

Finally, we must decide whether the relevant date at which to consider the English conditions is the date on which the English statute was passed or the rule of law in question was first enunciated, or 1870 . There is authority on this point, for the Appellate Division of the Supreme Court of Alberta in In re Simpson Estate ${ }^{\prime 8}$ held that the first alternative should be selected, because the essence of the problem is whether the reason for the adoption of the English rule in question would be equally applicable to conditions in Alberta. This decision was affirmed on other grounds by the Supreme Court of Canada, and treated as binding in the Trial Division by Egbert J. in In re Budd Estate. ${ }^{10}$ The reasoning of Chief Justice Harvey in the Simpson case certainly has much merit, but it is submitted that an even stronger case can be made for considering the social conditions in England as they existed in 1870, and therefore the reasons why the rule in question was retained in England rather than the reasons for its original development. It is true that there are a certain number of archaic rules of English law whose rationale long ago ceased to apply, but a good many of these had been remedied by legislation before 1870, and in any event the examination of English social conditions in 1870 need not preclude a conclusion that such a rule performed no useful function at that time, and so should not be applied in Canada. Far more important, however, is the large body of statutes and rules of law which were laid down for reasons forgotten centuries ago in England,

10 (1867) L.R. 4 Eq. 295; see Maclaren, Allhusen v. Whittel: Is It Law in Ontario? (1959)

i Fraser Y. Kirkpatrick (S.C. en banc 1907) 5 W.L.R. 286, 289; Hellens v. Densmore [1957] (Alta

[1928] S.C.R. 329. 3 W.W.R. 534, reog. [1927] 2 W.W.R. 104; affd. on other grounds

40 (S.C. Alta. 1958) 24 W.W.R. 383 
yet which persist today as the foundation of our law. Our whole system of land tenure, for instance, depends upon feudal tenure and the statute Quia Emptores, ${ }^{30}$ while the Statute of Uses ${ }^{31}$ continues to have significance for real property law, even though Henry VIII's motives for securing passage of the statute have been of merely academic concern for three hundred years. ${ }^{\circ 1}$ Indeed, it is entirely possible that the whole motivation for the development of that most cherished institution, the trust, was tied up with the incidents of feudal tenure and the difficulties of livery of seisin. Yet would anyone dare to suggest that the trust or the fee simple was not received as part of the law of any Canadian common law province?

In 1908 an ingenious counsel suggested ${ }^{\text {s2 }}$ a line of reasoning whereby Imperial statutes not intended to have effect outside England might nevertheless be in force in Alberta even if passed after 15 July 1870 . His contention was that the law in force in the West was that of $15 \mathrm{July}$ 1870 only insofar as it was not altered by (inter alia) Imperial statutes "applicable" to the Territories. "Applicable", he reasoned, must bear the same meaning it had been found to have where it first appeared in the same section of the North-West Territories Act, and so must mean "suitable". Therefore an Imperial Act of (say) 1874 in force proprio vigore only in England would, by the 1886 Act, be in force in Alberta and Saskatchewan if it amended rules of law which were in force in these provinces, and so was "suitable" to be applied in them. The answer to this argument was, of course, that the word "applicable" bore different meanings in the two places it was used in the section, for had this line of reasoning been correct, there would have been no point to naming 15 July 1870 or any other date as a "cut-off" point for the reception of English law. Indeed the application of virtually all current Imperial legislation from time to time would in practice largely destroy the legislative automony of Canada and Alberta.

The mere fact that the bulk of the English common law was received into the Canadian common law provinces does not, of course, affect the normal rules as to which courts' decisions bind other courts. No Canadian court is bound by the decision of any English court other than the Judicial Committee of the Privy Council, ${ }^{\circ 2 a}$ and it follows therefore that Canadian courts are free to disagree with English courts as to the proper interpretation of the common law ${ }^{33}$ (or, presumably, of an English statute). Therefore, Canadian courts should be free not only to disagree with the precise manner in which English courts have developed the common law, but also to develop its details for themselves. An Alberta court ought to be able, for instance, to disagree with an English decision of 1866, or to derive the same conclusions from previous English decisions

50 (Imp.) $18 \mathrm{Ed} .1$ (st. 1) c. 1.

81 (Imp.) 27 Hen. 8 c. 10.

s1a Hanbury, Modorn Equity 10, 12-13, 24-25 (8th ed. 1962).

32 Brand Y. Griffin (S.C. Alto. 1908) 9 W.L.R. 427; Accord, Gray v. Nattonal Trust Co. (S.C. Alta. 1915) 8 W.W.R. 1061.

siza Safeway Stores Ltd. v. Harris (Man. C.A.) [1948] 4 D.L.R. 187; cf. Robins v. National Trust Co. (P.C. (Can.j) [1927] A.C. 515.

53 R. v. Cyr. (S.C. Alta.) [1917] 3 W.W.R. 849. 857; Mackoroecki v. Yachimyc, aupra; Fiewelling v. Johnston (Alta. C.A. 1921) 16 Alta. L.R. 409 , 413-14: Stott v. Raby (Alta. D.C.) [1934] 3 W.W.R. 625, 628, reversed (S.C. Alta.) at 690; Maclaren, loc. cit. supra at 400; 15 Corpus Jurls Secundum 619 (8. 11 (b)); yet cf. the remarks of Idington J. in in re Church (B.C.C.) [1923] 3 W.W.R. 405 ; R. V. Hylend (1898) 24 V.L.R. 101, R. v. Scully (N.Z. C.A. 1603) 23 N.Z.L.R. 380, 382, 384, 
of 1840 and 1812 as an English court happened to derive in 1885 . Therefore, the mere fact that an English rule was first enunciated after the date on which a particular province received English law does not preclude the courts of that province from following the English decision. ${ }^{34}$ In practice, of course, this is precisely what Canadian courts have done, and modern English decisions are continually being cited and followed by Canadian courts. It may be otherwise, however, with respect to any rules which have entered the common law in England from custom after the date on which the province received English law, and which rules have not been developed by English courts purely from previous decisions. ${ }^{35}$

III

In practice it is often difficult to predict which rules of law and which statutes will be held to be applicable, and most cases on the subject offer little guidance, being more concerned with the particular rule or statute under consideration than the general principles which must govern the matter. The following principles are, however, capable of being deduced from the authorities, and may be of some assistance:

1. Statutes are less likely to be found applicable than are common law rules. $^{\text {se }}$

2. A statute may be applicable only in part..57

3. A statute or rule will, however, be in force throughout the entire province, or not at all, and so the question is whether it is applicable to all, or substantially all, of the province. ${ }^{58}$

4. A statute or rule fundamentally necessary to the carrying on of business and the administration of justice as now practised, is in force. ${ }^{30}$

5. A statute or rule recognized expressly or impliedly by the local legislature to be in force is in force..$^{80}$

6. It is a strong indication of applicability that the local courts have impliedly recognized the rule or statute as being in force, over a long period of time. ${ }^{.1}$

7. A statute or rule is not in force which was originally intended to apply only to one part of England, or to only one particular institution in England. ${ }^{02}$ But it should make no difference that the statute was passed only for England and had no force proprio vigore outside England.

8. A statute ameliorating the rigors or injustice or unsuitability of the common law, or simplifying procedure, will probably be in force. ${ }^{\text {"I }}$

9. A statute curtailing the royal prerogative will probably be in force. ${ }^{04}$

10. A statute in favor of the liberty of the subject will probably be in force."

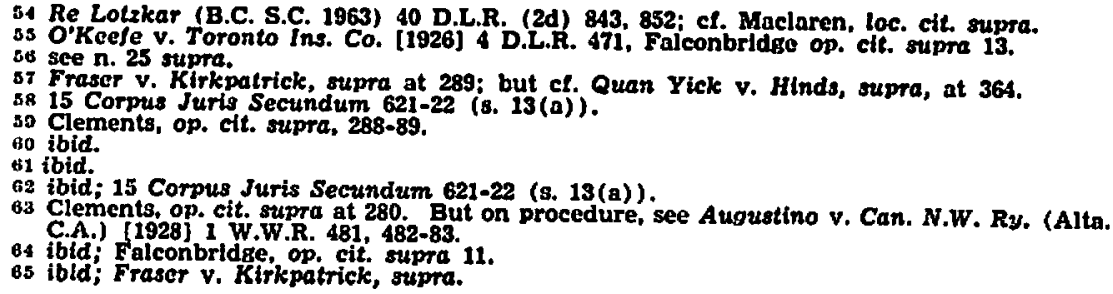


11. Applicability may refer to the physical conditions and climate, ${ }^{66}$ or to the social conditions ${ }^{07}$ and public beliefs, ${ }^{, 8}$ or customs and practice ${ }^{\mathrm{AO}}$ of the province.

12. In the absence of such a difference in conditions or attitudes between England and the province a rule or statute, it is suggested,70 will not be inapplicable merely because it has been criticized by English judges as being unjust or unwise, for this would be to usurp the function of the legislature. Sed quaere.

13. A rule or statute will not of course be in force if it is in fact incapable of being applied in the province for want of persons or things to which it could apply ${ }^{71}$ or institutions in which it could be applied. ${ }^{72}$

But this rule must be subject to the caveat that mere apparent lack of powers or jurisdiction in any provincial court to enforce or apply the rule or statute will not be sufficient for this purpose, for the provincial superior courts are presumed to have all jurisdiction except that which is expressly denied them, ${ }^{i 3}$ and as soon as an institution to which the English law could apply is established, the law becomes applicable. ${ }^{14}$

14. A rule or statute will not be in force where its application in the province would result in far more expense and inconvenience, or injustice, than in England. This is seen in the fact that native marriages have been held valid without the offices of a clergyman, contrary to the rule in $R$. v. Millis, ${ }^{7 s}$ where the majority of the natives were not Christians, and priests were few and far distant. is

15. Laws enacting police regulations are probably not in force. ${ }^{77}$

16. Revenue laws are almost certainly not in force. ${ }^{19}$

17. Laws for the establishment of the Church of England and the regulation of worship are probably not in force. ${ }^{70}$

In practice, the courts of Alberta and the Northwest Territories have on almost every occasion treated all the English common law rules as being in force, without any discussion as to why they were applicable. Alberta courts have, however, deviated from the English rule with respect to the right of a proprietor to appropriate surface waters, ${ }^{80}$ the right of a

60 Stott v. Raby, supra; 15 Corpus Jurts Socundum 621-22 (s. 13(a)).

of In re Simpson Est., supra; see also Edwards v. A.-G. Car. (P.C. (Can)) [1930] A.C. 124.

c8 Flewelling v. Johnston, supra at 413-14, Lollowing Keewatin Power Co. v. Kenora (Ont. C.A. 1906) 13 O.L.R. 237.

og 15 Corpus Juris Secundum 621-22 (s. 13(a)).

ro tbid.

71 Plested v. McLeod (Sask. D.C. 1910) 12 W.L.R. 700, 702-03.

12 Quan Yick Y. Hinds, suppa at 356; $R$. v. O'Connor (S.C. en banc 1885) 1 Terr. L.R. $4 ;$ A.-G. v. Stevart, supra, $n$, 3, at 11-12, 13 (no reristry office for enrolment of deeds in Grenada); Connors v. Egit (Alta. C.A.) [1924] I W.W.R. 1050, 1053.

is Board $y$, Board, supra in 43 .

74 Hellens v. Densmore [1957] S.C.R. 768. Thls case is considerably enlivened by the futle attempt of the British Columbja Legislature to re-enact the Divorce and Matrimonial Causes Act, 1857 (Imp.). In splendid dlaregard of the fact that the statute deals almost entlrely with marriage and divorce, which are ultra vires the province, and of the fact that the statute had been held to be in force in the province, so that no reenactment was necessary.

To (H.L. (E.) 1843) 10 Cl. \& F. 534, 8 E.R. 844.

76 R. V. Nanequlsaka (S.C. en banc 1859) 1 Terr. L.R. 211, 215; Penhas y. Tan Soo Eng (P.C. (Str. Setts.)) [1953] A.C. 304, 319; Re Noah Est. (S.C. N.W.T. 1962) 36 W.W.R. 577 . and comment. (1962) 2 Aita $L$. Rev. 121 .

77 Rules 15 to 17 inclusive in the text are derived from the extract from 1 Bl. Com. 107

quoted above (n. 36), and approved in Jex v. Mckinney (P.C. (Br. Hond.) 1889) 14

App.Cas. 77, A.G. V. Stewart, n. 3 supra, and Whicker v. Hume (H.L. (E.) 1858)

7 K.L.C. 124, 150-51, 161, 166; 11 E.R. 50, 61, 65, 67.

881 Bl. Com. 107.

80 Makowecki v. Yachimye (Alta. C.A. 1917) 11 W.W.R. 1279. 
woman to hold office, ${ }^{81}$ the applicability of the ad medium filum aquae rule, ${ }^{82}$ and the applicability of the Rule in Shelley's Case, ${ }^{83}$ while the English law as to accretions to riparian property, ${ }^{84}$ and exemptions from seizure $^{85}$ were held to be in force. A somewhat larger number of cases deal with the applicability of various English statutes to Alberta, but unfortunately few of the judgments reveal what factors were considered by the court in reaching its decision. Connors v. Egliso is an interesting decision, for although the Alberta legislature had by 1923 c. 5 s. 46 declared 13 Eliz. c. 5 (Imp.) on fraudulent conveyances to be in force in Alberta, the court held that section 3 was not in force because it was penal in character (and so conflicted with the Criminal Code), and sections 4 and 5 were not in force because their provisions could not be applied to the existing Alberta legal system. The Statute of Tenures, 1660 (Imp.) 12 Car. 2 c. 24 has been held by the Supreme Court of Canada to be in force in Alberta ${ }^{87}$ with the result that all land in the province is held by free and common socage except where modern legislation has changed the incidents of tenure. Though the Privy Council reversed this decision on other grounds and doubted that the statute was part of the law of the western provinces, their Lordships' decision seems to support the view that landholding by free and common socage was introduced by the Hudson's Bay Company Charter of $1670 .^{\text {s8 }}$ It is unfortunate, however, that in the judgment of the Privy Council the distinction between Imperial statutes in force in Alberta proprio vigore, and those passed for England but in force because of the 1886 statute, was not more clearly drawn.80 4 \& 5 Anne c. $16 \mathrm{s.} 9$ (on assignments by lessors) is in force, ${ }^{00}$ but not 26 Geo. 2 c. 33 (marriage) as regards natives in remote areas. ${ }^{01}$ Other Acts which have been held in force are $5 \& 6 \mathrm{Wm} .4$ c. 54 and Archbishop Parker's tables on the prohibited degrees of marriage, ${ }^{02}$ Thellusson's Act (on accumulations), ${ }^{\text {,3 }}$ the Wills Act, 1837, ${ }^{04}$ the Divorce and Matrimonial Causes Act, 1857, ${ }^{93}$ the Court of Probate Act, 1857; ${ }^{06}$ the Partition Act, $1868,{ }^{97}$ and the Debtors' Act, $1869 .^{\text {ss }}$

\section{IV}

To this point it has been assumed that the North-West Territories Act, 1886, and the Alberta Act were the only statutes relevant to the introduction of English law into Alberta, but this is in fact not the case, and the

81 R. v. Cyr (Alta. C.A.) [1917] 3 W.W.R. 849. See also Edroards v. A.G. Can. (P.C. (Can.)) [1930\} A.C. 124

2 Flewelling v. Johnston $n$. 53 supra, but ef. Can. Explorations Ltd. v. Rotter [1961] S.C.R. 337.

B3 In re Simpson Est., n. 48 supre.

yt Clarke v. Edmonton n. 33 supra.

Rs Stott v. Raby n. 33 supra.

so See n. 72 supra.

47 Huggard Ascels Ltd. v. A.-G. Alta. [1951] S.C.R. 427, 435, 443, 446

As (P.C. (Can.) [1953] A.C. 420, 442; 8 W.W.R. (N.S.) 561, 570 .

89 [1953) A.C. 420, 441-42. The same may be sald of Syndicat Lyonnals du Klondike v. MeGrade (1905) 36 S.C.R. 251, 271 . 0. Skrypmete v. Huculak (S.C. Alta.) [1947] 1 W.W.R. 713. The statute Is c. 16 in Rulthead,

D1 $R$. v. Nanequisaka n. 76 supra.

02 In re Seidler (S.C. Alta.) [1929] 2 W.W.R. 645.

03 (Imp.) 39 \& 40 Geo. 3, c. 98; Re Burng Bat. (Alta. C.A. 1861) 25 D.L.R. (2d) 427

o4 in re Church (Alta. C.A.) [1922] 3 W.W.R. 1207, 1220, 1226, affd. (S.C.C.) [1923] 3 W.W. $\mathrm{N}, 405,406$.

Walker v. Walker (P.C. (Man.)) [1919] 2 W.W.R. 935; Board v. Board (P.C. (Alta.)) [1919] 2 W.W.R. 940 .

96 in re Rutherford Est. (Alta. C.A.) [1942] 1 W.W.R. 567.

97 Wikstrand $v$. Cavanaugh [1936] I W.W.R. 113; In re Patrtition Act (S.C. Alta. 1951)

98 Fraser v. Ktrkpatrick (S.C. en banc 1907) 5 W.L.R. 286 . 20 W.W.R. (N.S.) 517. 
broad principles outlined above must be qualified in several respects. In the first place, the present Criminal Code, while it continues in force in each province the criminal law which was previously in force there, also expressly continues in force all common law rules which justify or excuse any act. ${ }^{\theta 0}$ It is strange that English statutes giving such defences are not mentioned also, and a question might arise as to whether "common law" might here be taken in the sense in which it is taken in many American states, as including some English statutes. ${ }^{100}$ Nothing is said about the rules of the common law being "applicable": does this mean that common law defences to crimes are revived whether or not they are suitable to the conditions of present-day Canada? This section bears the qualifying words "except in so far as they are altered by or are inconsistent with this Act or any other Act of the Parliament of Canada." Does that refer only to criminal legislation negativing such common law defences, or does it leave untouched the prerequisite of applicability laid down by the 1886 Act of Parliament? Is the NorthWest Territories Act, 1886, such an "other Act of the Parliament of Canada" which is inconsistent? In such matters one would normally choose the construction most favorable to the liberty of the subject, but one hesitates to do so here lest it lead to absurd results, such as a revival of benefit of clergy. ${ }^{101}$ An equally important provision of the Criminal Code $^{102}$ prohibits convictions for common law offences or offences against Imperial or pre-Confederation statutes, notwithstanding anything in the Code or any other Act. The Code does not specify, however, whether all legal significance is thereby removed from these former offences or not, nor is it clear whether such a provision would be intra vires the Parliament of Canada. Does this provision affect tortious liability, deodands, escheat, or forfeiture to the Crown, for instance? Might a contract still be void because its consideration falls within the ancient definitions of engrossing, forestalling, or regrating? ${ }^{103}$

The Bills of Exchange Act ${ }^{104}$ makes the common law and law merchant apply to bills of exchange in cases not provided for by the Act, and though no date for the ascertainment of English law is given, presumably that applying previously for each province is intended to be retained, though one might argue that this provision took effect on the date that Canada's first Bills of Exchange Act received royal assent (15 May 1890) or came into force (1 September 1890), and that was the date on which the English law was ascertained and introduced into Canada. However, as the purpose of this Act was for the most part to codify the law rather than to change it, the former alternative is probably preferable. Section 9 of this Act states (as did earlier Upper Canada legislation) that two Imperial statutes of George III are not to apply to Canada, but unfortunately no mention whatever is made of 48 Geo. 3 c. 88 , which might still be in force in some Canadian provinces, or

00 (Can.) 2-3 Elz. 2 c. 51 s. 7 ; It is to be noted that (Can.) 14 Geo. 6 c. 12 had already made the criminal law of Newloundland uniform with that of Canada by repeallng Nfld. Cons. Stat (3d) c. 95.

10015 Corpus Juris Secundum 615 (8. 4).

101 In Ontario or the Maritimes, that is, for benefit of clergy was abollshed by (Imp.) 728 Geo. 4 c. 28 s. 6.

202 (Can.) 2-3 Ellz. 2, c. 51 s. 8.

109 These ancient offences' historles are glven in 4 Bl. Com. 158-59; they were abolished in 1844 by (Imp.) 7 \& 8 Vict. c. 24.

104 R.S.C. 1952 c. 15. 
of $23 \& 24$ Vict. c. 111 s. 19 or $26 \& 27$ Vict. c. 105 , which were intended to modify the law of bills of exchange.

Another statute which has a great deal to say about the introduction of English rules and statutes is the Judicature Act. ${ }^{108}$ Sections 15(1), 16, and 17 cause no problem, and tie in well with the North-West Territories Act, 1886, for they also make use of the date 15 July 1870:

"15. (1) For the administration of the laws for the time being in force within the province, the Court [the Supreme Court of Alberta] possesses within the Province, in addition to any other jurisdiction, rights, powers, incidents, privileges and authorities that immediately before its organization were vested in or capable of being exercised within the Province by the Supreme Court of the North-West Territories, the jurisdiction that on the fifteenth day of July, 1870, was in England vested in ...."

[Then follows a list of English courts.]

"16. For the purpose of removing any doubt, but not so as to restrict the generality of section 15, it is declared that the Court has the like jurisdiction and powers that by the laws of England were, on the fifteenth day of July in the year 1870, possessed and exercised by the Court of Chancery in England in respect of

(a) fraud, mistake and accident, ...."

[The list is then continued with an enumeration of other subject matters.]

"17. The rules of decision in matters mentioned in section 16, except where otherwise provided, shall be the same as governed the Court of Chancery in England in like cases on the fifteenth day of July, 1870."

Section 15 (2) is not so straightforward, however:

"(2) The jurisdiction mentioned in subsection (1) includes

(a) the jurisdiction that at any time before the organization of the Court was vested in or capable of being exercised by all or any one or more of the judges of the said courts, sitting in Court or chambers or elsewhere, when acting as judges or a judge pursuant to a statute, law or custom,

(b) all the powers given to any such Court or to any judges or judge by a statute, and

(c) all ministerial powers, duties and authorities incident to any and every part of the jurisdiction so conferred."

No time is given for measuring the jurisdiction of the English courts referred to, and indeed one may ask whether the reference in paragraph (a) to "any time" does not destroy the certainty of time gained by the mention of 15 July 1870 in section 15 (1). However, the reference in subsection (2) of section 15 to the first subsection may indicate that subsection (2) is to be but a guide to the interpretation of the first subsection, and is not to enlarge the limits set in subsection (1). Even more uncertain is section $26(b)(v)$ :

"26. The Appellate Division ...

(b) has jurisdiction and power, subject to the provisions of the Rules of Court, to hear and determine ...

(v) all other petitions, motions, matters or things whatsoever that might lawfully be brought in England before a Divisional Court of the High Court of Justice or before the Court of Appeal."

This is most disconcerting, for if the law is taken as always speaking, then this section seems to work an incorporation into the law of Alberta of whatever legislation is passed from time to time in England on the jurisdiction of appellate courts. Does this mean that an Alberta barrister must look to current British legislation to find the jurisdiction of Alberta courts, and that the powers of the Appellate Division will wax and wane

108 R.S.A. 1955 c. 164. 
as British legislation and rules of procedure are amended? The same comments apply to section 33:

"33. In the case of lunatics and their property and estates, the jurisdiction of the Court includes, subject to the Rules of Court, the jurisdiction that, in England, is conferred upon the Lord High Chancellor by a Commission from the Crown under the Sign Manual."

This pattern is repeated in section 32 , paragraphs (a), (b), and (d), where it will suffice to quote only the first paragraph:

"32. In every civil cause or matter commenced in the Supreme Court, law and equity shall be administered by the Court according to the following rules:

(a) if a plaintiff or petitioner claims to be entitled

(i) to an equitable estate or right,

(ii) to relief upon any equitable ground

(A) against a deed, instrument or contract, or

(B) against a right, title or claim whatsoever asserted by a defendant or or

(iii) to any relief founded upon a legal right,

the Court shall give to the plaintiff or petitioner such relief as would be given by the High Court of Justice in England in a suit or proceeding for the same or a like purpose; . ..."

Paragraphs (b) and (d) are similarly worded. Here again it appears that the law of England from time to time on these matters is incorporated into the law of Alberta, and this is all the more serious because section 32 lays down substantive rules of law to be followed, not mere procedure or jurisdiction. In order to avoid doubt on these matters and to make all the substantive law of Alberta uniform, it would seem desirable to amend these provisions to make them refer to English law, practice, and jurisdiction as it existed on $15 \mathrm{July} 1870$. If it is desired to incorporate amendments to English law since that date (and this seems to be the case, in view of the provisions of the Judicature Acts of 1873 and $1875^{100}$ ), these amendments should be set out in Alberta legislation where they will be easily accessible, and their nature and extent apparent to all.

We have noted above that an English statute or rule of law may be part of the law of Alberta only if it was in force in England on the 15 July 1870, and is not in force in Alberta if enacted later, even though it may deal with subject matter similar to that found in Alberta, and so may be suitable to Alberta conditions. Therefore any changes in the law after 1887 must have come from legislation of Canada, the Northwest Territories, Alberta, or statutes of the Parliament at Westminster specifically intended to apply to the Empire, and passed before $1931 .{ }^{107}$ The courts have interpreted such changes in the law since 1887 broadly, $^{108}$ and have included not only express or implied repeal or amendment of the laws in force in $\mathbf{1 8 7 0}$, but also later laws merely affecting the $\mathbf{1 8 7 0}$ laws. Thus the mere fact that Canada in 1875 made a married woman liable to a separate suit in respect of her separate debts and torts was held to remove the rationale for the rule which had existed in 1870 that her husband must be joined in any suit against her because he would be liable: the 1875 legislation "affected" the English law, so making it inapplicable. ${ }^{100}$ This case is all the more significant in that the later

203 C. . . 29 supra.

107 See Colonial Laws Valldity Act, 1865 (Imp.) 28 \& 29 Vlct. c. 63 s. 1; Statute of Westminster, 1931 (Imp.) 22 Geo. 5 c. 48.4.

$108 \mathrm{As}$ in Huggard Assets Ltd. V. A.-G. Alta. n. 88 apra.

100 Quinn v. Beales (Alta. C.A.) [1924] 3 W.W.R. 337. 342-43. 
legislation was passed between 15 July 1870 and the passage of the NorthWest Territories Act in 1886, and so could not be said to have been a later amendment of the law as provided in 1886. This serves to point out the fact that the 1886 legislation refers to English laws which "have not been, or are not hereafter" repealed. [Emphasis added.]

The present state of the law in Alberta with respect to the applicability of English law is unsatisfactory, in part because uncertainty exists in some areas as to what the law is, and also because parts of the law are found only in old English statutes, couched in obscure language and printed only in expensive tomes not commonly available to the ordinary lawyer. What is needed is some thorough research on English statutes which might or might not be in force in Alberta. (Rules of English case law are for the most part so well known and accessible through standard reference works that this investigation could place greatest emphasis on statutes). When the research is completed, a reform bill along the lines of that passed in Victoria in 1922 should be put before Parliament and the provincial legislature. This Australian measure

(i) re-enacted in toto certain fundamental English statutes, such as the Statute of Uses,

(ii) reprinted appropriate parts of other English statutes at the appropriate place in the revised statutes,

(iii) listed a number of English statutes whose suitability might still be ruled upon in the future by the courts, and

(iv) expressly repealed a long list of other English statutes. ${ }^{110}$

The British have been pruning and tidying their statute books for almost a century. The Province of Quebec has had a Civil Code for the same length of time. Is it not time for Canadians in the common law provinces to reorder their own houses in the interest of greater certainty, accessibility, and rationality of the law?

\section{TABLE OF ENGLISH STATUTES IN FORCE IN CANADA}

This table was compiled in an attempt to list all the English statutes which have been declared by a Canadian court or legislative body to be in force or not to be in force in some part of Canada. It is an enlarged and up-dated version of one which appeared as Appendix $\mathbf{C}$ of Clements' Canadian Constitution 1060 (2d ed. 1916), and the Editors wish to acknowledge the kind consent given by the Carswell Company Limited to the use made here of that material.

The references to the Revised Statutes of Ontario, 1897 are up to date, although the statutes mentioned are reprinted for convenience in the latest revision of Ontario statutes. The references to statutes printed in the introductory pages of the Revised Statutes of British Columbia, 1897 may also be read as referring to the volume of miscellaneous statutes published in 1913 (and sometimes referred to as volume 4 of the Revised

110 Paton. The Commonwealth of Australia: The Development of its Latos and Constitution 5 (1952). But ef. Moore. A Century of Victorian Law (1984) 16 J. Comp. Les. (3d
series) 175, 179 . 
Statutes of British Columbia, 1911). The references to the Revised Statutes of British Columbia, 1911, are taken from the concordance published in volume 3 of that revision, of which there is no more recent version.

Because of the extreme diversity of subject matter of the statutes concerned, systematic research in this area is difficult, so that there are undoubtedly many omissions from this table, which the Editors would be pleased to have called to their attention.

Further cases upon the subject may be found in the Australian Digest, and Corpus Juris Secundum.

\begin{tabular}{|c|c|c|c|c|}
\hline & \multirow{2}{*}{$\begin{array}{l}\text { J.E.C. } \\
\text { Authority }\end{array}$} \\
\hline Statute & 8ubject Matter & $\begin{array}{l}\text { Whether } \\
\text { In } \\
\text { Force }\end{array}$ & Province & \\
\hline Magna Carta & Constit. Law & $\begin{array}{l}\text { Yes } \\
\text { Yes }\end{array}$ & B.C. & $\begin{array}{l}\text { Meisner v. Fanning } 3 \text { N.S.R. } \\
\text { 97; The Dart, Stewart } 44 \\
\text { Printed in R.S.B.C. 1897 p. Xvii } \\
\text { In re Munshi Singh (B.C. } \\
\text { C.A. 1914) } 6 \text { W.W.R. 1347, } \\
\text { 1371 }\end{array}$ \\
\hline Charter of Hen. 3 & Constit. Law & Yes & N.S. & Meisner v. Fanning 3 N.S.R. 97 \\
\hline 52 Hen. 3 c. 17 & Guardianship & Yes & B.C. & Incorp. into R.S.B.C. 1911 c. 107 \\
\hline 13 Ed. 1 c. 18 & Elegit & Yes & N.S. & $\begin{array}{l}\text { Caldwell v. Kinsman } 2 \text { N.S.R. } \\
398\end{array}$ \\
\hline 13 Ed. 1 c. 19 & Debt & Yes & B.C. & Incorp. into R.S.B.C. 1911 c. 4 \\
\hline 13 Ed. 1 c. 23 & Personal Rep. & Yes & B.C. & Incorp. into R.S.B.C. 1911 c. 4 \\
\hline \multirow[t]{2}{*}{$\begin{array}{r}18 \mathrm{Ed} .1 \text { (st. 1) c. } 1 \\
\text { c. } 2\end{array}$} & $\begin{array}{l}\text { Quia Emptores } \\
\text { Quia Emptores }\end{array}$ & $\begin{array}{l}\text { Yes } \\
\text { Yes }\end{array}$ & $\begin{array}{l}\text { B.C. } \\
\text { Ont. }\end{array}$ & $\begin{array}{l}\text { Printed in R.S.B.C. } 1897 \text { p. xliii } \\
\text { Re-enacted as R.S.O. } 1897 \text { c. } \\
330\end{array}$ \\
\hline & & Yes? & Alta. & $\begin{array}{l}\text { A.-G. v. Huggard Assets [1951] } \\
\text { S.C.R. } 427,446 \text {, cf. [1953] } \\
\text { A.C. } 441\end{array}$ \\
\hline 33 Ed. 1 c. 1 & Champerty & Yes & Ont. & $\begin{array}{l}\text { Re-enacted as R.S.O. } 1897 \text { c. } \\
327\end{array}$ \\
\hline 34 Ed. 3 c. 1 & Justices & Yes? & Ont. & $\underset{\text { S.C.R. } 361}{\text { Mackenzie v. Martin [1954] }}$ \\
\hline 4 Ed. 3 c. 7 & Personal Rep. & Yes & B.C. & Incorp. Into R.S.B.C. 1911 c. 4 \\
\hline 15 Ed. 3 c. 5 [sic] & & Yes & B.C. & Incorp. into R.S.B.C. 1911 c. 4 \\
\hline 25 Ed. 3 (st. 5 ) c. 5 & Executors & Yes & B.C. & Incorp. into R.S.B.C. 1911 c. 4 \\
\hline 27 Ed. 3 c. 17 & Statute of Staples & Yes & N.S. & The Dart, Stewart 44 \\
\hline 28 Ed. 3 c. 13 & Aliens & No & N.S. & $\begin{array}{l}\text { R. v. Burdell (1861) } 5 \text { N.S.R. } \\
126 \text {, Nolan v. MeAdam (1906) } \\
39 \text { N.S.R. } 380\end{array}$ \\
\hline $31 \mathrm{Ed} .3$ (st. 1) c. 11 & Administrators & Yes & B.C. & Incorp. into R.S.B.C. 1911 c. 4 \\
\hline 34 Ed. 3 c. 1 & Justices & $\begin{array}{l}? \\
\text { No }\end{array}$ & $\begin{array}{l}\text { Alta. } \\
\text { B.C. }\end{array}$ & $\begin{array}{l}\text { R. v. Poffenroth [1942] } 2 \\
\text { W.w.R. 362, 364 } \\
\text { Frey v. Fedoruk (B.C. C.A.) } \\
\text { [1949] 2 W.W.R. 604 }\end{array}$ \\
\hline 1 Ric. 2 c. 12 & Escape & $\begin{array}{l}\text { Yes } \\
\text { No }\end{array}$ & $\begin{array}{l}\text { N.S. } \\
\text { N.B. }\end{array}$ & $\begin{array}{l}\text { Clements } \\
\text { Wilson v. Jones } 6 \text { N.B.R. } 658 \text {, } \\
\text { Jameg v. MeLean } 8 \text { N.B.R. } \\
\text { 164, Doe d. Allen v. Mutray } \\
4 \text { N.B.R. } 359\end{array}$ \\
\hline
\end{tabular}




\begin{tabular}{|c|c|c|c|c|}
\hline Statule & 8ubjeet Matter & $\begin{array}{l}\text { Whether } \\
\text { In } \\
\text { Force }\end{array}$ & Province & Authority \\
\hline 5 Ric. 2 c. 7 & Forcible Entry & Yes? & B.C. & $\begin{array}{l}\text { Frey v. Fedoruk (B.C. C.A.) } \\
\text { [1949] } 2 \text { W.W.R. 604 }\end{array}$ \\
\hline 2 Hen. 4 c. 7 & Nonsuit & Yes & N.S. & $\begin{array}{l}\text { Grant v. Protection Ins. Co. } 1 \\
\text { N.S.R. } 12\end{array}$ \\
\hline 8 Hen. 6 c. 29 & Aliens & No & N.S. & R. v. Burdell 5 N.S.R. 126 \\
\hline 23 Hen. 6 c. 7 & Sheriff & Yes & B.C. & $\underset{210}{\text { Incorp. into R.S.B.C. } 1911 \text { c. }}$ \\
\hline 23 Hen. 6 c. 9 s. 1 & Sheriff & Yes & B.C. & Incorp. into R.S.B.C. 1911 c. 17 \\
\hline 23 Hen. 6 c. 10 & Sheriff, Bail & No? & N.S. & $\begin{array}{l}\text { Jackson v. Campbell (1855) } 1 \\
\text { N.S.R. }{ }_{18}\end{array}$ \\
\hline \multirow[t]{2}{*}{11 Hen. 7 c. 12} & $\begin{array}{l}\text { forma } \\
\text { pauperis }\end{array}$ & No & Alta. & $\begin{array}{l}\text { Augustino v. Can. N.W. Ry. } \\
\text { (Alta. C.A.) [1928] } 1 \text { W.W.R. } \\
481\end{array}$ \\
\hline & & Yes & B.C. & $\begin{array}{l}\text { Bland v. Agnewo (B.C. C.A.) } \\
\text { [1932] } 3 \text { W.W.R. } 222\end{array}$ \\
\hline 7 Hen. 8 c. 4 & Damages & Yes & N.S. & $\begin{array}{l}\text { Freeman v. Harrington } 5 \\
\text { N.S.R. } 358\end{array}$ \\
\hline 8 Hen. 8 c. 16 & Forfeiture & Yes & N.S. & $\begin{array}{l}\text { Wheelock v. McKeown } 1 \text { N.S.R. } \\
\text { 41, Miller v. Lanty } 1 \text { N.S.R. } \\
\text { 161, Scott v. Henderson 3 } \\
\text { N.S.R. 115; cf. Smyth v. } \\
\text { MeDonald } 5 \text { N.S.R. 274; but } \\
\text { see Emerson v. Maddison } \\
\text { [1906] A.C. } 569\end{array}$ \\
\hline 18 Hen. 8 c. 16 & Forfeiture & Yes & N.S. & See note to $8 \mathrm{Hen} .8$ c. 16 \\
\hline 21 Hen. 8 c. 4 & Executor & Yes & B.C. & Incorp. into R.S.B.C. 1911 c. 4 \\
\hline 21 Hen. 8 c. 5 & Statute of Sewers & Yes & B.C. & Incorp. into R.S.B.C. 1911 c. 5 \\
\hline 25 Hen. 8 c. 22 & Marriage & Yes & Ont. & $\begin{array}{l}\text { Hodgins v. McNeil 9 Grant Ch. } \\
\quad 309\end{array}$ \\
\hline \multirow[t]{3}{*}{27 Flen. 8 c. 10} & Statute of Uses & $\begin{array}{l}\text { Yes } \\
\text { Yes }\end{array}$ & $\begin{array}{l}\text { B.C. } \\
\text { N.B. }\end{array}$ & $\begin{array}{l}\text { Printed in R.S.B.C. } 1897 \text { p. xlv } \\
\text { Doe d. Hanington v. McFadden } \\
\text { (N.B. C.A. 1836) } 2 \text { N.B.R. } 153\end{array}$ \\
\hline & & Yes & N.S. & $\begin{array}{l}\text { Shey v. Chisholm (1853) } 2 \\
\text { N.S.R. } 52\end{array}$ \\
\hline & & Yes & Ont. & $\underset{\text { R31 }}{\text { Re-enacted as R.S.O. } 1897 \text { c. }}$ \\
\hline 27 Hen. 8 c. 10 & Enrolment & $\begin{array}{l}\text { Yes } \\
\text { No }\end{array}$ & N.S. & $\begin{array}{l}\text { Doe d. Hanington v. McFadden } \\
\text { (N.B. C.A. 1836) 2 N.B.R. } 153 \\
\text { Berry v. Berry } 16 \text { N.S.R. } 66\end{array}$ \\
\hline 28 Fen. 8 c. 7 & Marriage & Yes & Ont. & $\begin{array}{l}\text { Hodgins v. McNeil } 9 \text { Grant Ch. } \\
\quad 309\end{array}$ \\
\hline 28 Hen. 8 c. 16 & Marriage & Yes & Ont. & $\begin{array}{l}\text { Hodgins v. McNeil } 9 \text { Grant Ch. } \\
\text { 309 }\end{array}$ \\
\hline 31 Hen. 8 c. 1 & Partition & Yes & N.S. & $\begin{array}{l}\text { Doane v. McKenny } 2 \text { N.S.R. } \\
\text { 328, Cran e v. Blackeadar } \\
\text { (1895) 40 N.S.R. 100; see } \\
\text { Freeman v. Morton } 3 \text { N.S.R. } \\
\text { 340, 353 }\end{array}$ \\
\hline \multirow[t]{2}{*}{32 Hen. 8 c. 9} & Pretended Titles & Yes & N.S. & $\begin{array}{l}\text { Wheelock v. Morrison } 7 \text { N.S.R. } \\
\text { 337; Scott v. Henderson } 3 \\
\text { N.S.R. 115, 123 }\end{array}$ \\
\hline & & Yes & Ont. & $\begin{array}{c}\text { Beasley v. Cahill } 2 \text { U.C.Q.B. } \\
320\end{array}$ \\
\hline
\end{tabular}




\section{Statute}

32 Hen. 8 c. 34

32 Hen. 8 c. 38

32 Hen. 8 c. 39

$5 \& 6$ Ed. 6 c. 3

5 \& 6 Ed. c. 16

$1 \& 2$ Ph. \& M. c. 13

5 ㅂliz c. 4

13 Eliz c. 4

13 Eliz. c. 5

18 Eliz. c. 5

29 Eljz. c. 4

31 Eliz. c. 5

43 Eliz. c. 2

43 Eliz c. 4, Preamble
Subjeet Mattex

Leases

Marriage

Crown Debtors

Holidays

Sale of Offices

Habeas Corpus

Apprentices

Crown Debts

Fraudulent Conveyances

Qui tam actions

Sheriff's costs

Informers

Poor Relief

Charities
Whether

Force Province

Authority

Yes B.C. Printed in R.S.B.C. 1897 p. li

Yes Ont. Hodgins v. McNeil 9 Grant Ch. 300

Yes N.B. R. v. McLaughlin, Steven's N.B. Dig.

No N.S. Uniacke v. Dickson (N.S. C.A. 1848) 2 N.S.R. 287

? Man. Referred to, $R$. v. Sawchuk (Man. K.B.) [1923] 2 W.W.R. $824,829 \mathrm{ff}$.

Yes Ont. R. v. Mercer 17 U.C.Q.B. 602, Foote v. Bullock 4 U.C.Q.B. $480, R$. v. Moodie 20 U.C.Q.B. 389

Yes B.C. Printed in R.S.B.C. 1897 p. xxxxil

No Ont. Fish v. Doyle, (1831) Drap. 328, Dillinghem v. Wilson (1841) 6 U.C.Q.B. (O.S.) 35, Shea v. Choat (1845) 2 U.C.Q.B. 211, 221

No N.S. Uniacke v. Dickson (N.S. C.A. 1848) 2 N.S.R. 287

Yes Alta. 1923, c. 5, s. 46; but see Connors v. Egli (Alta. C.A.) [1924] I W.W.R. 1050. The 1923 statute is still in force: Goyan v. Kinesh [1945] 2 D.L.R. 749

Yes B.C. Incorp. into R.S.B.C. 1911 c. 93

Yes N.B. Re Geldart 31 C.B.R. 119

Yes N.S. Tarratt v. Sawyer 1 N.S.R. 46, Moore v. Moore (1880) 13 N.S.R. 525, Graham v. Bell (1884) 17 N.S.R. 90, Cromwell v. Comeau (S.C. N.S. 1957) 8 D.L.R. (2d) 676

Yes Ont. Millar v. McTaggart (Ont. C.P.D. 1890) 20 O.R. 617

Yes Sask. Stewart v. Zacharuk (Sask. K.B.) [1949] 1 W.W.R. 213

Yes Ont. Garrett v. Roberts 10 O.A.R. 650

No N.B. Kavanagh v. Phelon 3 N.B.R. 472

No B.C. R. v. Crown Zellerbach $L$ td. (B.C. C.A. 1956) 20 W.W.R. 523 , but cf. Taylor v. Mackintosh (B.C. C.A.) [1824] 3 W.W.R. 97, 98

Yes B.C. R. v. Hall (B.C. Cty. Ct.) [1941] 2 W.W.R. 245

Yes Man. Re Angell Est. (Man. Q.B. 1955) 16 W.W.R. (N.S.) 342 
Statute

-body of statute

43 Eliz. c. 6
43 Eliz. c. 8
7 Jac. 1 c. 5
21 Jac. 1 c. 3 s.
21 Jac. 1 c. 12
21 Jac. 1 c. 14
21 Jac. 1 c. 16
1 Car. 1 c. 1
16 Car. 1 c. 10
12 Car. 2 c. 24

13 Car. 2 c. 2

17 Car. 2 c. 8

22 \& 23 Car. 2 c. 10

29 Car. 2 c. 3
Costs

Executors

Not Guilty plea

Monopolies

Not Guilty plea

Forfeiture

Limitations

Lord's Day

Lord's Day

Star Chamber

Statute of Tenures

Costs

Administrators

Intestacy

Statute of Frauds
Whether

Porce Province

Authortty

Yes Sask. Re Patriotic Acre Fund (Sask. C.A.) [1951] 2 D.I.R. 624

No Man. In re Oldfield Est. (No. 2) (Man. K.B.) [1949] 1 W.W.R. 540

Yes N.B. Kelly v. Jones 7 N.B.R. 473

Yes B.C. Incorp. into R.S.B.C. 1911 c. 4

No Sask. Plested v, McLeod (Sask. D.C. 1910) 12 W.L.R. 700

Yes Ont. Re-enacted as R.S.O. 1897 c 323

No Sask. Plested v. McLeod (Sask. D.C. 1910) 12 W.L.R. 700

Yes N.S. Smyth v. MeDonald 5 N.S.R. 274 ; Scott v. Henderson (1843) 3 N.S.R. 115, 118

Yes B.C. Incorp. into R.SB.C. 1911 c. 145

Yes Man. Bk. of Montreal v. Robshaw (Man. Cty. Ct. 1935) 44 Man L.R. 114

Yes B.C.

Declared in force by R.S.B.C. 1911 c. 219 . But see Criminal Code 1955 8s. 7, 8.

Yes B.C. See note to 1 Car. 1 c. 1

No Ont. Stark v. Ford 11 U.C.Q.B. 363

Yes? Alta.

Huggard Assets Ltd. v. A.-G. Alta. [1951] S.C.R. 427, 443, 446; but cf. the doubts of the P.C., [1953] A.C. 441, 442.

Yes B.C. Incorp, into R.S.B.C. 1911 c. 107

Yes N.B. Gilbert v. Sayre 7 N.B.R. 512

Yes B.C. Incorp. into R.S.B.C. 1911 c. 4

Yes B.C. Incorp. into R.S.B.C. 1911 c. 4

Yes? Man. In re Lama Est. (Man. K.B.) [1941] 3 W.W.R. 35.

Yes Alta. Eiserman v. Stark (Alta. C.A.) [1941] 1 D.L.R. 153

Yes B.C. Re-enacted as R.S.B.C. 1911 c 92; Robinson v. McAdam [1948] 2 W.W.R. 425

? Man. Not introduced into Man. originally because passed after 1670: Sinclair v. Mulligan 5 Man. L.R. 17, Templeton v. Stewart 9 Man. L.R. 487

Yes N.S. Crosby v. Temple (N.S. C.A.) [1940] 2 D.L.R. 554

Yes Ont. Richmond v. Simpson [1940] S.C.R. 1 
29 Car. 2 c. 7

30 Car. 2 (st. 1) c. 7

31 Car. 2 c. 2

1 Jac. 2 c. 17

1 Wm. \& M. c. 18

2 Wm. \& M. c. 5

4 Wm. \& M. c. 4

8 \& 9 Wm. \& M. c. 11

9 \& 10 Wm. 3 c. 15

$10 \mathrm{Wm} .3$ c. 22

(c. 16 in Ruffhead)

1 Anne (st. 2) c. 6

4 Anne c. 16

s 9
ss. 9,10
s. 12
s. 19
s. 20
s. 27

4 \& 5 Anne c. 3

5 Anne c. 9
Subject Matter

Lord's Day

Executors

Habeas Corpus

Administrators

Religious

meetings

Distress

Bail

Admin. of Justice

Awards

Infants

Escape

Bail Bonds

Account by CoTenant

Account

Escape
Whether

Force Province Authority

Yes Sask. Balaberda v. Mucha (Sask. C.A. 1960) 25 D.L.R. (2d) 760

Yes B.C. See note to 1 Car. 1 c. 1 , and Gibbons v. Koepke (S.C. B.C. 1951) 4 W.W.R. (N.S.) 560,561

Yes B.C. Incorp. into R.S.B.C. 1911 c. 4

Yes B.C. Printed with R.S.B.C. 1897 p. xxix. In re Munshi Singh (B.C. C.A. 1914) 6 W.W.R. 1347, 1371. See also 56 Geo. 3 c. 100.

Yes? Man. R. v. Colemen (Man. C.A. Ch.) [1935] 3 W.W.R. 161, but cf. R. v. Collins (Man. C.A. 1962) 39 W.W.R. 32

Yes B.C. Incorp. into R.S.B.C. 1911 c. 4

Yes Ont. Reid v. Inglis 12 U.C.C.P. 191

Yes B.C. Incorp into R.S.B.C. 1911 c. 65

Yes B.C. Incorp. into R.S.B.C. 1911 c. 17

Yes B.C. Incorp. into R.S.B.C. 1911 c. 25

? B.C. In re Ward 1 B.C.R. (pt. 1) 114

Yes B.C. Incorp. into R.S.B.C. 1911 c. 107

No Ont. Hesketh v. Ward (1867) 17 U.C.C.P. 667

Yes N.B. Doe d. Hanington v. McFadden (N.B. C.A. 1836) 2 N.B.R. 153

Yes Alta. Skrupnek v. Huculak (S.C. Alta.) [1947] 1 W.W.R. 713

Yes B.C. Incorp. into R.S.B.C. 1911 ce. 4, 126

Yes B.C. Incorp. into R.S.B.C. 1911 c. 25

Yes B.C. Incorp, into R.S.B.C. 1911 c.

Yes B.C. Incorp. into R.S.B.C. 1911 c. 17

Yes B.C. Spelman v. Spelman (No. 2) (B.C. C.A.) [1944] 1 W.W.R. 691

? N.B. Bowes v. Bamford [1853] 1 D.L.R. 440, rev'd. [1954] S.C.R. ix

Yes Sask. King v. King (Sask. K.B. Ch.) [1944] 3 W.W.R. 242

Yes Sask. Blacklaw v. Beveridge (Sask. C.A.) [1939] 3 W.W.R. 511

No Ont. Hesketh v. Ward (1867) 17 U.C.C.P. 667 


\section{Btatute}

7 Anne c. 5

8 Anne c. 18

9 Anne c. 14

6 Geo. 1 c. 18

2 Geo. 2 c. 19

4 Geo. 2 c. 21

4 Geo. 2 c. 28

7 Geo. 2 c. 20

9 Geo. 2 c. 5

9 Geo. 2 c. 36

11 Geo. 2 c. 19

13 Geo. 2 c. 18
Sabject Matter

Citizenship

Distress

Gaming

Bubble Act

Distress for Rent

Cltizenship

Distress

Foreclosure

Fortune Telling

Mortmain

Apportionment

Certiorari
Whether

Force Province Authority

Yes N.S. Salter v. Hughes (1863) 5 N.S.R. 409

Yes B.C. Incorp. into R.S.B.C. 1911 c. 126

? B.C. See Carr v. Abbs (B.C. Cty. Ct.) [1939] 1 W.W.R. 249

No Ont. Bk, of Upper Can. v. Bethune (Ont. C.A. 1835) 4 U.C.Q.B. (O.S.) 165

Yes Alta. Royal Trust Co. v. Mills [1923] 1 W.W.R. 796 Yes N.S. Salter v. Hughes (1863) 5
N.S.R. 409

Yes B.C. Incorp. into R.S.B.C. 1911 c. 126

Yes B.C. Incorp. Into R.S.B.C. 1911 c. 168

Yes Ont. R. v. Milford 20 O.R. 306

No B.C. In re Pearse Est. (S.C. B.C. 1903) 10 B.C.R. 280 and cases cited there

No Man. In re Fenton Est. (Man. C.A.) [1920] 2 W.W.R. 367

No N.B. $R a y$ v. Methodist Church (1881) 6 S.C.R. 308; Doe d. Hagen v. St. James (1878) 18 N.B.R. 479

Yes Ont. But only on the grounds of local legislative recognition: Doe d. Anderson v. Todd (C.A. 1846) 2 U.C.Q.B. 82; Whitby v. Lipscombe (C.A. 1875) 23 Grant Ch. 1 , and cases there cited; Smith v. Methodist Church 16 O.R. 199; Butland v. Gillespie 16 O.R. 486

No Sask. Re Miller Est. (Sask. S.C.) [1918] 1 W.W.R. 929

No $\underset{\text { ada }}{\text { Gren- }}$ A.-G. v. Stewart (Ch. 1817) 2 Mer. 143, 35 E.R. 895

No N.S.W. Whicker v. Hume (1858) 7

tortia Canterbury v. Wyburm (P.C. (Vict.)) [1895] A.C. 89

No Br.

Hon-

duras

Jex v. McKinney (P.C. (Br. Hond.) (1889)) 14 App. Cas. 77

Yes B.C. Incorp. into R.S.B.C. 1911 c. 65

Yes B.C. Incorp. into R.S.B.C. 1911 c. 35

No N.B. Ex parte Ritchie 4 N.B.R. 75; Ex parte Bustin 7 N.B.R. 211 
Statute

14 Geo. 2 c. 17

14 Geo. 2 c. 37

15 Geo. 2 c. 30

19 Geo. 2 c. 37

20 Geo. 2 c. 19

22 Geo. 2 c. 40

22 Geo. 2 c. 46

24 Geo. 2 c. 40

24 Geo. 2 c. 44

26 Geo. 2 c. 33

ss. 11,12

32 Geo. 2 c. 28 s. 4
s. 12

6 Geo. 3 c. 25

9 Geo. 3 c. 16
Subject Matter

Nonsuit

Bubble Act

Lunatics' Marriage

Marine Ins.

Apprentices

Sale of Liquor

Attorneys

Debt

Constables' Protection

Marriage

Arrest

Apprentlces

Nullum Tempus Act
Whether

Force Province

Authority

No N.S. R. v. Porter (1888) 20 N.S.R. 352, 357; cf. R. v. McFadden 18 N.S.R. 426, McDonald v. Ronan 19 N.S.R. 25

Yes Ont. See reference in $R$. v. Porter 20 N.S.R. 352, 358.

Yes N.B. Doe d. Hanington v. McFadden (N.B. C.A. 1836) 2 N.B.R. 153

No Ont. Bk. of Upper Can. v. Bethune (C.A. 1835) 4 U.C.Q.B. (O.S.) 165

No Man. Meanwell v. Meanwell (Man. C.A.) [1941] 1 W.W.R. 154

Yes B.C. Incorp. into R.S.B.C. 1911 c. 116

Yes B.C. Incorp. into R.S.B.C. 1911 c. 107

No Ont. See note to 5 Eliz. c. 4

No Ont. Leith v. Willis 5 U.C.Q.B. (O.S.) 101, Heartley v. Hearns 6 U.C.Q.B. (O.S.) 452

Yes Ont. (In part) Dunn v. O'Reilly 11 U.C.C.P. 404

Yes B.C. Incorp. into R.S.B.C. 1911 c. 142

Yes B.C. Savinkoff v. Borodula (S.C B.C. 1957) 26 W.W.R. 370

Yes Ont. R. v. Roblin (1862) 21 U.C.Q.B. 355, Hodgins v. McNeil 9 Grant Ch. 309; O'Connor v. Kennedy (1888) 15 O.R. 22; Lawless v. Chamberlain (1889) 18 O.R. 309

No. N.W.T. Connolly v. Woolrich (1867) 11 L.C. Jur. 197; not as regards Indians in remote parts: $R$. v. Nanequisaka 1 Terr. L.R. 211

No Ont. Lawless v. Chamberlain supra; May v. May (1910) 22 O.L.R. 559

Yes B.C. Incorp. into R.S.B.C. 1911 c. 12

Yes B.C. Incorp. into R.S.B.C. 1911 c. 210

Yes B.C. Incorp. into R.S.C.B. 1911 c. 107

Yes B.C. A.-G. Can. v. W. Highbie Investments Ltd. [1945] S.C.R. 385, 428

Yes N.S. Scott v. Henderson (1843) 3 N.S.R. 115, 117

Yes Ont. R. v. McCormick (1859) 18 U.C.Q.B. 131; A.-G. Can. v. Krause (Ont. C.A.) [1956] O.R. 675 
Statute

Subject Matter

13 Geo. 3 c. 21

14 Geo. 3 c. 48

14 Geo. 3 c. 78 s. 83

s. 86

19 Geo. 3 c. 70

21 Geo. 3 c. 49

26 Geo. 3 c. 86

28 Geo. 3 c. 49

28 Geo. 3 c. 56

35 Geo. 3 c, 113

38 Geo. 3 c. 87

$39 \& 40$ Geo. 3 c. 98
Citizenship

Life Insurance

Fires Spreading
Certiorari

Lord's Day

Fire on Ships

Magistrates

Marine Ins.

Licensing

Administrators

Accumulations
Whether

In

Force Province

Yes N.S.W.

Tes N.S.

NS.R. 409

Yes B.C. Incorp. into R.S.B.C. 1911 c.

No Sask. Croton Bakery v. Pfd. Accident (Sask. CA.) [1933] 2 W.W.R. 33

Yes Ont. Stinson v. Pennock (1868) 14 Grant Ch. 604; Carr v. Fire Assce. Assn. (Ont. C.P.D. 1887) 14 O.R. 487

No Sask. Royal Bank v. Pischke (Sask. D.C.) [1933] 1 W.W.R. 145

Yes Alta. Johrson v. Conrow (S.C. Alta.) [1951] 4 D.L.R. 493, 503

Yes B.C. Laidlaw v. Crow's Nest Ry. 14 B.C.R. 169, 42 S.C.R. 355; Ingre v. Barker (S.C. B.C. 1960) 31 W.W.R. 590; Flymn v. Vallstrom (S.C. B.C. 1955) 16 W.W.R. (N.S.) 335

Yes Man. Mainella v. Wilding (Man. C.A.) [1948] 1 W.W.R. 366

Yes Ont. Gaston v. Wald (1860) 18 U.C.Q.B. 586; Canada S. Ry. v. Phelps (1888) 14 S.C.R. 132

Yes Sask. Bettcher v. Tumer (Sask. D.C. 1913) 25 W.L.R. 136, 139, 140 Walt v. Newton Motors (Sask. C.A.) [1950] 2 D.L.R. 351

Yes On

Baldwin v. Roddy 3 U.C.Q.B. (O.S.) 166, and see Gregory v. Flanagan 2 U.C.Q.B. (O.S.) 552

Yes Ont.

R. v. Barnes 45 U.C.Q.B. 276

Yes Ont.

Torrance v. Smith 3 U.C.C.P. 411, Hearle v. Ross 15 U.C.Q.B. 259

No Ont

R. v. Row (1864) 14 U.C.C.P. 307

Yes B.C. Incorp. into R.S.B.C. 1911 c. 116

Yes Nfld. Yonge v. Blaikie (1822) 1 Nfld R. 277, 283 (1901 ed.)

Yes B.C. Incorp. into R.S.B.C. 1911 c. 4 (Thellusson's

Act)
Yes B.C. Incorp. into R.S.B.C. 1911 c. 3

Yes Alta. Re Burns Est. (Alta. C.A. 1961) 25 D.L.R. (2d) 427 
Statute

43 Geo. 3 c. 46

43 Geo. 3 c. 140

44 Geo. 3 c. 102

48 Geo. 3 c. 106

48 Geo. 3 c. 143

51 Geo. 3 c. 37

56 Geo. 3 c. 100

56 Geo. 3 c. 139

59 Geo. 3 c. 69

4 Geo. 4 c. 34

4 Geo. 4 c. 76 s. 22

7 \& 8 Geo. 4 c. 71

9 Geo. 4 c. 14

11 Geo. 4 \& 1 Wm. 4 c. 40

11 Geo. 4 \& 1 Wm. 4 c. 46

11 Geo. 4 \& 1 Wm. 4 c. 47 11 Geo. 4 \& 1 Wm. 4 c. 65

11 Geo. 4 \& 1 Wm. 4 c. 68 11 Geo. 4 \& 1 Wm. 4 c. 70

$1 \& 2 \mathrm{Wm} .4$ c. 32

2 \& 3 Wm. 4 c. 71
Bublect Matter

Costs

Habeas Corpus

Habeas Corpus

Expiration of Acts

Licensing

Lunatics' Marriage

Habeas Corpus

Apprentices

Foreign

Enlistment

Apprentices

Marriage

Execution

Infants' Contracts

Executors

Appointment

Debt

Infants

Stage Coaches

Admin. of Justice

Lord's Day

Prescription
Whether

Porce Province

Authority

Yes Man. Fonseca v. Jones (1911) 21

Man. R. 168, Re Alkins Trusts (1961) 35 W.W.R. 143

Yes Sask. Re Fossum Est. (1960) 32 W.W.R. 372

Yes B.C. Incorp. into R.S.B.C. 1911 c. 12 (Repealed in part, 32 \& 33 Vict. c. 83 8. 20)

Yes B.C. Printed with R.S.B.C. 1897 p. xxorvi

Yes B.C. Printed with R.S.B.C. 1897 p. xxxvii

Yes B.C. Incorp. into R.S.B.C. 1911 c. 1

? Nfld. See Yonge v. Blaike (1822) 1 Nfld. R. 277 (1901 ed.)

No Man. Meanwell v. Meanwell (Man. C.A.) [1941] 1 W.W.R. 154

Yes B.C. Printed with R.S.B.C. 1897 p. xxxviii $R$. v. Shin Shim (B.C. C.A. 1937) 52 B.C.R. 80, [1938] S.C.R. 378, 384-85

Yes Man. R. v. Artiss (Man. K.B.) [1950] 1 W.W.R. 60

Yes B.C. Incorp. into R.S.B.C. 1911 c.

Yes Ont. R. v. Schram (1864) 14 U.C.C.P. 318

Yes B.C. Incorp. into R.S.B.C. 1911 c.

No B.C. Penner v. Penner (S.C. B.C.) [1947] 4 D.L.R. 879

Yes B.C. Incorp. into R.S.B.C. 1911 c. 12

Yes B.C. Incorp. into R.S.B.C. 1911 c. 145

Yes Sask. Molymeux v. Traill (Sask. D.C. 1915) 32 W.L.R. 292

Yes B.C. Incorp. into R.S.B.C. 1911 c. 4

Yes Man. Re-enacted in Man.: In re Aitken Est. (Man. Q.B. 1953) 8 W.W.R. (N.S.) 385

Yes B.C. Incorp. Into R.S.B.C. 1911 c. 181

Yes B.C. Incorp. Into R.S.B.C. 1911 c. 4

Yes B.C. Incorp. into R.S.B.C. 1911 c.

Yes B.C. Incorp. into R.S.B.C. 1911 c. 27

Yes B.C. Incorp. into R.S.B.C. 1911 c. 17

Yes B.C. See note to 1 Car. 1 c. 1.

Yes B.C. Incorp. into R.S.B.C. 1911 c. 
Statute

$3 \& 4$ Wm. 4 c. 27

$3 \& 4$ Wm. 4 c. 42

3 \& 4 Wm.. 4 c. 74

s. 28

3 \& 4 Wm. 4 c. 104

3 \& 4 Wm. 4 c. 105

4 \& 5 Wm. 4 c. 22

$4 \& 5$ Wm. 4 c. 76

5 \& 6 Wm. 4 c. 41

$5 \& 6 \mathrm{Wm}, 4$ c. 54

$5 \& 6$ Wm. 4 c. 62

7 Wm. 4 \& 1 Vict. c. 26

7 Wm. 4 \& 1 Vict. c. 28

$1 \& 2$ Vict. c. 45

$1 \& 2 \mathrm{Vic}$ c. 110

ss. 14,15

2 \& 3 Vict. c. 11
Subjeet Matter

Administrators, etc.

Admin. of Justice

Admin. of Justice

Debt

Dower

Landlord and Tenant

Poor Relief

Gaming

Marriage

Oaths

Wills Act

Limitations

Habeas Corpus

Int. on Judgment

Lis Pendens

Infants
Whether

In

Provinee

Authority

Yes Man. Stall v. Yarosz (Man. C.A. 1964) 47 W.W.R. 113

Yes B.C. Incorp. into R.S.B.C. 1911 cc. 4, 68,145

Yes B.C. Incorp. into R.S.B.C. 1911 cc. 4. 12,145

Yes? Sask. Adlard v. Greensill (Sask. D.C. 1910) 14 W.L.R. 536, 537-38

Yes B.C. Incorp. into R.S.B.C. 1911 c. 77

? B.C. Triangle Storage Ltd. v. Porter (B.C. C.A.) [1941] 3 W.W.R. 892,896

Yes B.C. Incorp. into R.S.B.C. 1911 c. 4

Yes B.C. Incorp. into R.S.B.C. 1911 c. 68

Yes B.C. Incorp. into R.S.B.C. 1911 c. 126

? B.C. Dedek v. Mantyka (B.C. Fam. Ct. 1960) 32 W.W.R. 361; Re Creery (B.C. Cty. Ct. 1960) 39 W.W.R. 620; Lang v. Lang (Sask. K.B.) [1948] 1 W.W.R. 479

? B.C. See Carr v. Abbs (B.C. Cty. Ct.) [1939] 1 W.W.R. 249

Yes Man. Windsor Hotel Co. v. Silverman (Man. K.B.) [1934] 3 W.W.R. 249

Yes Alta. In re Seidler (S.C. Alta.) [1929] 2 W.W.R. 645

No Ont. Hodgins v. McNeil 9 Grant Ch 309

Yes B.C. Incorp. into R.S.B.C. 1911 c. 241

Yes Alta. In re Church (Alta. C.A.) [1922] 3 W.W.R. 1207, 1220 1226, aff'd. (S.C.C.) [1923] 3 W.W.R. 405, 406

Yes B.C. Incorp. into R.S.B.C. 1911 c. 145

Yes B.C. Printed with R.S.B.C. 1897 p. xli

Yes B.C. Foley v. Webster (S.C. B.C. 1893) 3 B.C.R. 30 . Incorp. into R.S.B.C. 1911 cc. 12,70

Yes Sask. Miller-Morse Hdwe. Co. v. Smart (Sask. C.A.) [1917] 3 W.W.R. 1113

No Yukon Syndicat Lyonnais v. McGrade (1905) 36 S.C.R. 251

Yes B.C. Incorp. into R.S.B.C. 1911 c. 107. Repealed in part, 12 \& 13 Vict. c. 106 8. 1 
Statute

3 \& 4 Vict. c. 82

s. 1

$3 \& 4$ Vict. c. 86

$3 \& 4$ Vict. c. 90

$5 \& 6$ Vict. c. 45

6 \& 7 Vict. c. 73

8 \& 9 Vict. c. 16

$8 \& 9$ Vict. c. 18

8 \& 9 Vict. c. 106

8 \& 9 Vict. c. 109

9 \& 10 Vict. c. 93

$10 \& 11$ Vict. c. 96

11 \& 12 Vict. c. 44

11 \& 12 Vict. c. 49

12 \& 13 Vict. c. 45

$12 \& 13$ Vict. c. 74

$13 \& 14$ Vict. c. 21

$13 \& 14$ Vict. c. 23

13 \& 14 Vict. c. 60

14 \& 15 Vict. c. 99

$15 \& 16$ Vict. c. 24

15 \& 16 Vict. c. 55

15 \& 16 Vict. c. 57

15 \& 16 Vict. c. 86
Subject Matter

Infants$$
\text { Whether }
$$

Force Province Authority

Yes B.C. Incorp. into R.S.B.C. 1911 c. 107

Yes Sask. Miller-Morse Hdwe. Co. v. Smart (Sask. C.A.) [1917] 3 W.W.R. 1113

Church Discipline Yes B.C. Bishop of Columbia v. Cridge (S.C. B.C. 1874) I B.C.R. (pt. 1) 5

Yes B.C. Incorp. into R.S.B.C. 1911 c. 107

Copyright

Yes Ont. Black v. Imp. Book Co. (1804) 8 O.L.R. 9, aff'd. 35 S.C.R. 488

Solicitors

Yes Man. Re a Solicitor (Man. Q.B. 1955) 16 W.W.R. (N.S.) 463

Companies

Yes B.C. Incorp. into R.S.B.C. 1911 c. 40

Lands Clauses

Real Property

Gaming

Executors

Trustees

Limitations

Lord's Day

Admin. of Justice

Trustees

Statutes

Lord's Day

Trustees

Evidence

Wills

Trustees

Corrupt Practices

Chancery Procedure
Incorp. into R.S.B.C. 1911 c. 128

Yes B.C. Printed with R.S.B.C. 1897 p. liii Ct.) [1939] 1 W.W.R. 249

Yes B.C. Incorp. into R.S.B.C. 1911 c. 82

Yes B.C. Incorp. into R.S.B.C. 1911 c. 232

Yes B.C. Incorp. into R.S.B.C. 1911 c. 150

Yes B.C. See R.S.B.C. 1897 c. 177 , and Criminal Code ss. 7,8

Yes B.C. Incorp. into R.S.B.C. 1911 c. 35

Yes B.C. Incorp. into R.S.B.C. 1911 c. 232

Yes B.C. Incorp. into R.S.B.C. 1911 c. 1

Yes B.C. See R.S.B.C. 1897 c. 177, and Criminal Code ss. 7, 8

Yes B.C. Incorp. into R.S.B.C. 1911 c. 232

Yes Ont. Wyer v. Wyer [1947] O.R. 292

Yes B.C. Incorp. into R.S.B.C. 1911 c. 241

Yes B.C. Incorp. into R.S.B.C. 1911 c. 232

Yes B.C. Incorp. into R.S.B.C. 1911 c. 72

Repealed in part, 26 \& 27 Vict. c. 29 s. 10

? B.C. Not in force: Fieldhouse v. Nisbet (B.C. S.C.) [1950] 1 W.W.R. 142, yet incorporated in part into R.S.B.C. 1911 c. 86
? B.C. See Carr v. Abbs (B.C. Cty. 
Statute

16 \& 17 Vict. c. 59 s. 19

$17 \& 18$ Vict. c. 80 s. 58

$17 \& 18$ Vict. c. 113

18 \& 19 Vict. c. 43

$18 \& 19$ Vict. c. 67

$18 \& 19$ Vict. c. $90 \mathrm{s.} 2$

$19 \& 20$ Vict. c. 97

19 \& 20 Vict. c. 108 s. 4

19 \&. 20 Vict. c. 120

20821 Vict. c. 43

$20 \& 21$ Vict. c. 77

20 \& 21 Vict. c. 85
Stamp Act

Evidence

Administration

Infants

Bills of Exchange

Crown Costs

Admin. of Justice

Yes B.C.

County Courts

Settled Estates

\section{Summary Convictlons}

Probate Court

$$
\begin{aligned}
& \text { Divorce and } \\
& \text { Matrimonial } \\
& \text { Causes Act }
\end{aligned}
$$

\section{Anthority}

Jonasson $v$. Royal Transport (Man. C.A.) [1936] 3 W.W.R. 540

No. B.C. Hinton Electric Co. v. Bk. of Montreal (S.C. B.C. 1903) 9 B.C.R. 545

Yes Ont. R. v. Inness [1933] O.R. 169

Yes B.C. Incorp. into R.S.B.C. 1911 c. 4

Yes Man. Incorp. into Man. Wills Act: In re McEwen (Man. C.A.) [1941] 1 W.W.R. 129, 138; In re Kluner Est. (Man. K.B.) [1940] 3 W.W.R. 221

Yes B.C. Incorp. into R.S.B.C. 1911 c. 107

Yes Man. Can. Ble. of Commerce $v$. Adamson (S.C. Man. 1883) 1 Man. L.R. 3

No B.C. A.-G. v. Ruffner (S.C. B.C. 1906) 12 B.C.R. 299

Yes Man. Incorp. into Man. Q.B. Act: R. v. Thomas (Man. C.A.) [1948] 2 W.W.R. 444, 453-54

No Sask. R. v. Meilicke (No. 2) (Sask. C.A.) [1938] 2 W.W.R. 97, 138-39, 424

Incorp. into R.S.B.C. 1911 cc. 133 (ss. 1, 5), 92 (s. 3), 145 (ss. 9-11, 13, 14)

No B.C. Imperial Order in Council not in force: Reynolds v. Vaughan (S.C. B.C. 1872) 1 B.C.R. (pt. 1) 3

Yes Sask. Re Moffat Est. (Sask. Q.B. 1955) 16 W.W.R. (N.S.) 314

Yes B.C. R. v. Ah Pow (S.C. B.C.) 1880) 1 B.C.R. (pt. 1) 147

Yes Alta. In re Rutherford Est. (Alta. C.A.) [1942] 1 W.W.R. 567

Yes B.C. Incorp. into R.S.B.C. 1911 c. 4

Yes Alta. Board v. Board (P.C. (Alta.)) [1918] A.C. 956

Yes B.C. Sheppard v. Sheppard (1808) 13 B.C.R. 486, Watts v. Watts (P.C. (B.C.) [1908] A.C. 573; see Brown v. Brown (B.C. C.A. 1956) 20 W.W.R. 321. Densmore v. Densmore (B.C. C.A. 1956) 19 WW.R. 252, [1957] S.C.R. 768, and R.S.B.C. 1911 c. 67

Yes Man. Walker v. Walker (P.C. (Man.)) [1919] A.C. 947 
Btatute

s. 28

s. 32

s. 41

8. 55

$21 \& 22$ Vict. c. 27

21 \& 22 Vict. c. 95

$21 \& 22$ Vict. c. 108

$22 \& 23$ Vict. c. 35

23 \& 24 Vict. c. 106

$23 \& 24$ Vict. c. 126

$23 \& 24$ Vict. c. 127 s. 28

$23 \& 24$ Vict. c. 145

$24 \& 25$ Vict. c. 62

$24 \& 25$ Vict. c. 100 s. 45

$26 \& 27$ Vict. c. 118

$27 \& 28$ Vict. c. 95

$28 \& 29$ Vict. c. 60

28 \& 29 Vict. c. 78

30 \& 31 Vict. c. 69

$31 \& 32$ Vict. c. 40

32 \& 39 Vict. c. 48
Subject Matler

Chancery
Amendment

Probate

Divorce

Admin. of Justice

Land

Common Law
Procedure

Solicitors

Ld. Cranworth's Act

Limitations

Offences Against the Person

Companies

Executors

Dogs

Mortgages, Trustees

Mortgages

Partition

Companies
Whether

Force Province

Authorty

Yes Ont.

$20 \& 21$ Geo. 5 c. 14 (Can.); H. v. H. [1936] O.W.N. 78 (rev'd. on other grounds, [1936] O.R. 432)

Yes Sask. Fletcher v. Fletcher (Sask. C.A.) [1920] 1 W.W.R. 5

No Sask. May v, May (Sask. C.A.) [1934] 3 W.W.R. 471, Hauer v. Hauer (Sask. Q.B. 1956) 20 W.W.R. 89

Yes Sask. In re Belaney Est. (Sask. K.B.) [1939] 3 W.W.R. 591

No Sask. Davidson v. Davidson (Sask. C.A. 1952) 7 W.W.R. (N.S.) 272

No B.C. Scott v. Scott (B.C. C.A. 1891) 4 B.C.R. 316

Yes B.C. Robinson v. McAdam [1948] 2 W.W.R. 425

Yes B.C. Incorp. into R.S.B.C. 1911 c. 4 Yes See notes to $20 \& 21$ Vict. c. 85

Yes B.C. Incorp. Into R.S.B.C. 1911, cc. 133 (s. 21), 232 (ss. 23, 29, 30)

Yes B.C. Incorp. into R.S.B.C. 1911 c. 128

Yes P.E.I. Pictou Foundry Co. v. Dicks [1935] 2 D.L.R. 593

Yes Man. In re McCormack (Man. C.A.) [1936] 2 W.W.R. 78, 509

Yes Man. In re Nanton Est. (Man. K.B.) [1948] 2 W.W.R. 113

Yes B.C. Incorp. into R.S.B.C. 1911 c. 145

Yes Sask. Nykiforuk v. Kohut (Sask. D.C.) [1949] 1 W.W.R. 708

Yes B.C. Incorp. into R.S.B.C. 1911 c. 40

Yes B.C. Incorp. into R.S.B.C. 1911 c. 82

Yes Sask. Popp v. Hoffman (Sask. D.C. 1953) 10 W.W.R. (N.S.) 337

Yes B.C. Incorp. into R.S.B.C. 1911 c. 41

Yes B.C. Incorp. into R.S.B.C. 1911 c. 4

Yes Alta. Hicks v. Kennedy (Alta. C.A. 1957) 20 W.W.R. 517, and cases cited there

Yes B.C. Incorp. into R.S.B.C. 1911 c. 40

Yes Sask. Grunert v. Grunert (Sask. Q.B. 1960) 32 W.W.R. 509

Yes B.C. Incorp. into R.S.B.C. 1911 c. 40 


\begin{tabular}{|c|c|c|c|c|}
\hline Statute & Subject Matter & $\begin{array}{c}\text { Whether } \\
\text { In } \\
\text { Foree }\end{array}$ & Province & Authority \\
\hline \multirow[t]{3}{*}{$32 \& 33$ Vict. c. 62} & Debtors & Yes & Alta. & Fraser v. Kirkpatrick (S.C. \\
\hline & & Yes & Man. & $\begin{array}{l}\text { Re Bremner (Man. C. A. 1889) } \\
6 \text { Man. L.R. } 73\end{array}$ \\
\hline & & Yes & Sask. & $\begin{array}{l}\text { Pearce v. Kerr (Sask. D.C. } \\
\text { 1908) } 9 \text { W.L.R. 504 }\end{array}$ \\
\hline 32 \& 33 Vict. c. 68 s. 2 & Corroboration & Yes & Man. & $\begin{array}{c}\text { Cockerill v. Harison (Man. } \\
\text { C.A. 1903) } 14 \text { Man. L.R. } 366\end{array}$ \\
\hline 33 \& 34 Vict. c. 20 & Mortgages & Yes & B.C. & Incorp. into R.S.B.C. 1911 c. 41 \\
\hline 33 \& 34 Vict. c. 23 & Forfeiture & No & Sask. & $\begin{array}{l}\text { In re Noble Est. (Sask. D.C.) } \\
\text { [1927] } 1 \text { W.W.R. } 938\end{array}$ \\
\hline
\end{tabular}

